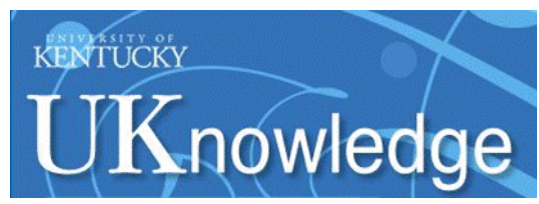

Kentucky Law Journal

Volume 100 | Issue 2

Article 3

2011

\title{
Material Witness Detentions After al-Kidd
}

Wesley MacNeil Oliver

Duquesne University

Follow this and additional works at: https://uknowledge.uky.edu/klj

Part of the Constitutional Law Commons

Right click to open a feedback form in a new tab to let us know how this document benefits you.

\section{Recommended Citation}

Oliver, Wesley MacNeil (2011) "Material Witness Detentions After al-Kidd," Kentucky Law Journal: Vol. 100: Iss. 2, Article 3.

Available at: https://uknowledge.uky.edu/klj/vol100/iss2/3

This Article is brought to you for free and open access by the Law Journals at UKnowledge. It has been accepted for inclusion in Kentucky Law Journal by an authorized editor of UKnowledge. For more information, please contact UKnowledge@lsv.uky.edu. 


\title{
Material Witness Detentions After al-Kidd
}

\author{
Wesley MacNeil Oliver
}

\section{INTRODUCTION}

I NNOCENCE is not clearly a prerequisite to detention under the Federal Material Witness Stature. That was the unremarkable principle the United States. Supreme Court unanimously announced in the 2010 term in Ashcroft v. al-Kidd. ${ }^{2}$ The Court was asked to resolve whether a witness could be constitutionally detained when the prosecutor is as interested in making a case against the witness as he is in securing testimony. ${ }^{3} \mathrm{~A}$ fivemember majority went even further. It held that not only does using a legitimate material witness warrant to arrest a criminal suspect not violate clearly established law, it does not violate the law at all. ${ }^{4}$

Despite the common sense of the majority's bottom line, the legal doctrine Justice Scalia used to reach the result was not as clear-cut as his opinion suggests. No court prior to al-Kidd had previously considered whether the government was permitted to have a legitimate and illegitimate basis for arresting a material witness. Existing precedent permitted arrests supported by probable cause to believe an individual had committed a crime, however minor, regardless of the government's motives. ${ }^{5}$ But existing precedent also provided that the government's motive for engaging in suspicionless intrusions mattered. ${ }^{6}$ Under this latter line of precedent, the government is not permitted to conduct a search or seizure without suspicion unless its purpose is for something other than the detection of crime. ${ }^{7} A l$-Kidd fell between these lines of precedent. Circumstances unique to al-Kidd made the government believe he was in possession of helpful information, but did not give the government an

I Associate Professor of Law and Director, Criminal Justice Program, Duquesne University School of Law. B.A., J.D., University of Virginia; LL.M., J.S.D., Yale. The Ninth Circuit's opinion in al-Kidd cited the author's work on the history of material witness detention yet without any supporting authority arrived at historical conclusion at odds with the author's. The author therefore filed an amicus brief with the United States Supreme Court in this matter correcting the lower court's misunderstanding of the historical record and supporting Ashcroft's position in the matter.

2 See Ashcroft v. al-Kidd, I3I S. Cr. 2074, 2084-85 (20 I ).

3 See id. at 2079.

4 See id. at 2085.

5 Whren v. United States, 5 I 7 U.S. 806, 813 (1996).

6 City of Indianapolis v. Edmond, 53 I U.S. 32, 45 (2000).

7 Id. at $45-46$. 
objective basis for believing him guilty of a crime. Practically, it would be hard to explain how a suspected member of al-Qaeda may not be detained on the same evidence permitting the detention of an innocent bystander, but practical considerations were not part of the Court's opinion. The Court's analysis suggested that the facts of the case easily situated it within the strain of authority requiring no assessment of the government's motives for the seizure.

This case drew a lot of attention for matters that were not part of the legal issues being debated. The New York Times observed that the decision "did not resolve whether the material witness law was misused under President George W. Bush," and of course that is correct. ${ }^{8}$ Only a very narrow issue was before the Court. The issue was, in fact, so narrow that one of the claims al-Kidd made against John Ashcroft appears to have survived the very short opinion. The Supreme Court found that the Constitution is not violated when material witnesses are detained as suspects. ${ }^{9}$ The Ninth Circuit, however, found for al-Kidd on an issue not addressed in Ashcroft's petition for certiorari. The lower court held that irrespective of the constitutionality of pretextual detentions, Ashcroft's instructions to make "aggressive" use of material witness detentions to hold suspects imposed a duty on him to ensure that prosecutors were only seeking material witness warrants where the statutory requirements were satisfied. ${ }^{10}$ The Supreme Court's decision does not appear to alter this basis of liability and a trial to determine whether he breached that duty could still occur.

The issues beyond the scope of the Court's opinion, which attracted considerable media attention, were very troubling. The application for a material witness warrant in al-Kidd's case did not seem to satisfy the statutory criteria and the conditions of his confinement were deplorable, as many of the justices observed. ${ }^{11}$

A number of early commentaries on this case concluded that the Court's concern about the underlying facts suggest that the Court will soon impose limits on the government's power to arrest and hold material witnesses. ${ }^{12}$ The rarity of material witnesses makes this conclusion seem unlikely and, more importantly, courts are in a less than optimal position to place constraints on material witness arrests.

8 Editorial, Qualified Immunity, Unqualified Doubt, N.Y. Times, June 1, 201 I, at A26.

9 al-Kidd, 13 I S. Ct. at 2085.

Io Al-Kidd v. Ashcroft, 580 F.3d 949, 964-65 (9th Cir. 2009), rev'd, I 3 I S. Ct. 2074 (201 I).

I I See al-Kidd, I3 I S. Ct. at 2089 (Ginsburg, J., concurring); al-Kidd, 580 F.3d at 951.

I2 See Qualified Immunity, Unqualified Doubt, supra note 8; Andrew Cohen, 8-o, My Foot: Material Witness Case Generates Material Differences, The Atlantic (May 3I, 20 I I, I 2: 14 PM), http:/www.theatlantic.com/national/archive/201 I/05/8-0-my-foot-material-witness-casegenerates-material-differences/239693/; Lyle Denniston, Opinion Recap: Narrow Ruling on Anti-Terrorism Tactic, SCOTUSblog (May 31, 201 I, 9:20 PM), http://www.scotusblog.

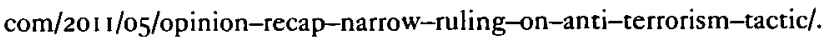


Neither the problems with the decision to arrest al-Kidd, nor the terms of his confinement, are matters courts are well equipped to prevent in future cases. The criteria for arrest under the Material Witness Statute are far from clear, giving the government extraordinary power over those it chooses to identify as witnesses. Like other vague terms, such as probable cause, it would require a number of decisions for courts to develop criteria placing meaningful limits on the government. Courts have further been reluctant in the past to identify the level of custody appropriate for detainees. ${ }^{13}$ Congress, by contrast, does not need the grist of individual facts to develop rules. It has institutional authority to consider the nature of criminal punishments, and by extension the terms of pre-trial and witness confinement. Congress has developed criteria for deciding when suspects can be detained pending trial and has delegated power to an executive agency to assess the level of confinement appropriate for federal prisoners.

The al-Kidd case hopefully will not be the last word on the limits on the government's power to detain material witnesses. The facts of al-Kidd's case vividly demonstrate that it should not be. The legal issue that brought the case into the national spotlight was, as a practical matter, rightly decided in favor of the government notwithstanding the substantial conflict in precedent prior to the case. The decision, expressly permitting use of the Material Witness Statute to hold suspects, does however make the case for limits on the statute more compelling. The government will not have the same interest in ensuring the minimum necessary restraints on witnesses if its goal is to pursue a case against them.

This Article will first recount the facts of the case and the basis for alKidd's lawsuit against John Asshcroft. It will then describe and critique the Ninth Circuit's opinion permitting the suit to go forward. The practically inescapable but poorly reasoned Supreme Court's opinion will then be considered. Finally, this Article will consider problems with the Material Witness Statute that were not before the Court.

\section{FACTS OF THE $A L-K I D D$ CASE}

On March 14, 2003, the United States Attorney's Office for the District of Idaho asked a federal magistrate to authorize the arrest of Abdullah alKidd as a material witness. ${ }^{14} \mathrm{~A}$ remarkably short and conclusory affidavit

13 While federal judges can make recommendations about the degree of confinement, and even the location of confinement, to the Bureau of Prisons, these decisions are merely advisory. See Adam J. Kolber, The Subjective Experience of Punishment, 109 Colum. L. Rev. 182 , 195 (2009) (citing 18 U.S.C. $\$ 362 \mathrm{I}(\mathrm{b})$ (2000)). Oddly, by contrast, courts are willing to conclude that conditions of confinement are cruel and unusual, regardless of the basis for imposing them. See, e.g., Brown v. Plata, I3 I S. Ct. 1910, 1923 (201 I) (finding prison overcrowding to be an Eighth Amendment violation).

14 First Amended Complaint and Demand for Jury Trial, al-Kidd, I3I S. Ct. 2074 (No. 10-98), 2010 WL 5096738, at *23-24. 
supporting the application for his arrest warrant stated that he had information "crucial" to the prosecution of Sami Omar al-Hussayen for the offenses of visa fraud and making false statements to the United States. ${ }^{15}$

Scott Mace, a Special Agent with the FBI in Boise, Idaho, informed the district court in this affidavit that during the course of investigating $\mathrm{Mr}$. alHussayen's visa and false statement offenses, "information was developed regarding the involvement of Abdullah [a]l-Kidd." ${ }^{16}$ The sum total of the "information" so discovered is related below:

[F]rom March 2000 to November 2001, an individual identified as Abdullah [a]l-Kidd, a/k/a Lavoni T. Kidd, and/or his spouse, Nadine Zegura, received payments from Sami Omar [a]lHussayen and his associates in excess of $\$ 20,000.00$. Al-Kidd traveled to Sana'a, Yemen, in August 2001 and remained there until April 2002, when he returned to the United States. Upon his return to the United States, [a]l-Kidd traveled to Moscow, Idaho, and met with [a]l-Hussayen's associates. While in Moscow, [a]l-Kidd emptied a storage facility which contained personal items belonging to him. Among those personal items were documents [a]l-Kidd left behind, which included a conference program for the second annual IANA conference in Dearborn, Michigan, in December 1994; a hotel receipt from Sacramento, California, dated 4/26/2001, in the name of Abdullah [a]l-Kidd, listing his company name as "[a] l-Multaqa;" and telephone numbers for IANA (734-5280006 ) and Basem Khafagi (734-481-1930). Khafagi is a former Director of IANA and former University of Idaho student (graduated in 1988) who was recently arrested in New York. ${ }^{17}$

Many aspects of this affidavit seem insufficient. The affiant never stated the nature of the lies al-Hussayen allegedly made to agents of the U.S. government, or the nature of visa fraud alleged. Without this information, it is impossible to comprehend how Abdullah al-Kidd's receipt of money from al-Hussayen, or al-Kidd's travel to Yemen could be relevant to the government's prosecution. The affidavit did not state what the initials IANA abbreviated. It most likely referred to the Islamic Assembly of North America, which was referenced in the al-Hussayen indictment, but the meaning of these initials were never stated in the affidavit. ${ }^{18}$ Nor was it even remotely clear how any ties al-Kidd may have had with such an organization demonstrated his knowledge of information bearing on alHussayen's prosecution for false statements and visa fraud. The affiant

15 Mace Affidavit, United States v. al-Hussayen, No. 03-048-C-EJL (D. Idaho Mar. 14, 2003) (No. 03-048-C-EJL), 2010 WL 5096738 at *64.

I6 Id. at $* 63$.

17 Id. at $* 63-64$.

18 Certainly this seems to be a question of draftsmanship rather than substance, though there are other possible organizations these initials could identify, including the Internet Assigned Numbers Authority or the Intermodal Association of North America. 
even identified al-Kidd only as "Kidd" in one of the paragraphs, while referring to him as "[a]l-Kidd" in the remainder. ${ }^{19}$

The indictment against Sami Omar al-Hussayen provides some context to the facts in the affidavit, but does not demonstrate how al-Kidd's testimony was relevant to the particular charges then pending against alHussayen. In essence, this indictment alleged that al-Hussayen, a Saudi national, was issued a visa to be in the United States for the sole purpose of studying to obtain his $\mathrm{Ph}$.D. in computer science at the University of Idaho and on a number of occasions represented to agents of the U.S. government that that was his sole purpose for being in the country. While in the United States, however, the government alleged, he was also retained by a number of entities to assist them with information technology and assisted the Islamic Assembly of North America (IANA) with substantial fundraising and technology. The indictment further alleged that the IANA's website disseminated "radical Islamic ideology the purpose of which was indoctrination, recruitment of members, and the instigation of acts of violence and terrorism." 20 . The indictment supported this characterization with a reference to an article that appeared on one of the organization's websites published by a radical Saudi sheikh in June 2001, who advocated suicide bombings or "bringing down an airplane on an important location that will cause the enemy great losses." ${ }^{21}$ Such stories, however, were also posted on the BBC's website. ${ }^{22}$

Whether al-Hussayen's involvement in these posts amounted to journalism, eerie prophecy, or an immediate incitement to the terrorist attacks of September 11, there was only one question for the court considering the government's request for a warrant to arrest al-Kidd: Did al-Kidd have information material to the prosecution that the government would be unable to obtain with a subpoena? And the government's case required that it prove that al-Hussayen had been in the country for some purpose other than his education. At most, the government alleged that al-Kidd knew al-Hussayen, had taken money from him, and had contact information for someone in this organization al-Hussayen was supporting. But these facts did little to demonstrate the government's need for al-Kidd's testimony against al-Hussayen. Was the government suggesting that alKidd's testimony could be used to demonstrate the extent of al-Hussayen's

\footnotetext{
I9 Mace Affidavit, supra note 15 , at *64.

20 al-Hussayen Indictment, al-Hussayen, No. 03-048-C-EJL, 2010 WL $509673^{8}$ at *73-74

2 I $I d$. at $* 75$. There was a superseding indictment and al-Hussayen was ultimately acquitted on all terrorism charges. For a characterization of al-Hussayen's website as reporting news and not advocating violence, see Adam D. Moore, Toward Informational Privacy Rights, 44 San Diego L. Rev. 809 (2007) and Alan F. Williams, Prosecuting Website Development Under the Material Witness Support to Terrorism Statute: Time to Fix What's Broken, 1 N.Y.U. J. LEGIS. \& Pub. Pol'y 365, 367-73 (2008).

22 See Moore, supra note $2 \mathrm{I}$, at 835 n.93.
} 
business interests? Or was his testimony to be used to demonstrate alHussayen's extensive role in the Islamic Assembly of North America?

It is certainly not clear from the affidavit used to support his arrest exactly how the government thought his testimony might be useful as it noted only that al-Kidd "is believed to be in possession of information germane to this matter which will be crucial to the prosecution." 23 To the extent al-Kidd's potential testimony bore on any of these matters, if it did at all, surely his testimony was not uniquely able to establish the elements of the crime alleged against al-Hussayen. The application further did not mention what information the government believed al-Kidd possessed, or how it was an essential part of the case against al-Hussayen. ${ }^{24}$ Whatever information al-Kidd possessed about al-Hussayen was in fact sufficiently trivial that al-Kidd was never summoned before a grand jury or called to testify in al-Hussayen's trial. ${ }^{25}$

'There were gross omissions in the affidavit. The government's request for a warrant to arrest al-Kidd contended that he had met with an associate of al-Hussayen after returning from a trip to Yemen and that he had taken $\$ 20,000$ from al-Hussayen. ${ }^{26}$ The affidavit did not say why al-Kidd had received this money. The affidavit did not mention that al-Kidd had a degree in computer programming and had been compensated for his work as an information technology specialist for the IANA. ${ }^{27}$

Parts of the Mace Affidavit suggest that the affiant hoped the magistrate reviewing it would simply draw the worst possible assumption about every Muslim entity or person identified. The affidavit did not make any effort to identify "[a]l-Multaqa." It further did not state what charge led to Basem Khafagi's recent arrest in New York, or even the municipality in New York where Khafagi was arrested. Seemingly the government was hoping the judge would draw a negative inference from the mere fact that a Muslim man from Idaho, whom al-Kidd knew, was arrested in one of the two jurisdictions al-Qaeda attacked. The reason for Khafagi's arrest, which the affidavit did not mention, was on a charge of bank fraud. ${ }^{28}$

For almost a century, federal courts have recognized that "bare bones" affidavits are insufficient for warrants. ${ }^{29}$ And notwithstanding the

23 Mace Affidavit, supra note I5, at *64.

24 See id. at *63-64; Application for Arrest Warrant of Material Witness, al-Hussayen, No. 03-048-C-EJL, 20 io WL 5096738 at *59-60.

25 First Amended Complaint and Demand for Jury Trial, supra note 14, at *38-39.

26 Mace Affidavit, supra note I5, at *63.

27 See First Amended Complaint and Demand for Jury Trial, supra note 14 , at *28.

28 Nicholas K. Geranios, Second Man with Ties to University of Idaho Arrested, SEatTle Times (Mar. 14, 2003 I 2:00 AM), http://community.seattletimes.nwsource.com/archive/? date $=200303$ I 4 \&slug=webarrest 14 .

29 E.g., United States v. Leon, 468 U.S. 897, 915 (1984); see Kenneth M. Murchison, Prohibition and the Fourth Amendment: A New Look at Some Old Cases, 73 J. Crim. L. \& Criminology 471, 506-1 I (1982). For a complete history of the evolution of the requirement 
extraordinary protection from civil liability given to officers possessing arrest or search warrants, officers are not entitled to immunity for trespass, false arrest, or civil rights actions if they rely on bare bones warrant applications. ${ }^{30}$ No reasonable officer should have thought he could have relied on a warrant obtained on the basis of such an application and certainly no federal judge should have issued such a warrant.

The government's affidavit did not even claim to satisfy any particular evidentiary threshold to justify this arrest. A warrant for an ordinary arrest requires probable cause to believe a crime has been committed and that the defendant has committed it. The Material Witness Statute does not specify the quantum of proof the government must satisfy to obtain a warrant, though many courts have assumed that the standard is probable cause. ${ }^{31}$ The government's bare bones affidavit failed to assert that it had probable cause that al-Kidd was in possession of helpful information. ${ }^{32}$ It merely concluded that al-Kidd was "believed to be in possession of information germane to this matter which will be crucial to the prosecution." 33 Remarkably, if this standard is correct, a man's liberty turns on satisfying a pleading requirement and nothing more. ${ }^{34}$

The facts supporting the government's conclusion that al-Kidd would be unavailable to provide evidence against al-Hussayen were even less substantial than the facts demonstrating that al-Kidd had "crucial" information. The government's affidavit stated, "Kidd [sic] is scheduled

that an adequate factual allegation be offered in a warrant application, see Fabio Arcila, Jr., The Death of Suspicion, 5I WM. \& MARY L. REv. I 275 (2010); Fabio Arcila, Jr., In the Trenches: Searches and the Misunderstood Common-Law History of Suspicion and Probable Cause, io U. PA. J. Const. L. I (2007); Wesley MacNeil Oliver, The Modern History of Prabable Cause, 78 TENN. L. Rev. 377, 382-94 (20 I I). But see Thomas Y. Davies, Can You Handle the Truth? The Framers Preserved Common-Law Criminal Arrest and Search Rules in "Due Process of Law"- "Fourth Amendment Reasonableness" is Only a Modern, Destructive, Judicial Myth, 43 TEx. TECH. L. Rev. 51, 77-78 n. 122 (2010).

30 See Leon, 468 U.S. at 922-24; see also Donald Dripps, Living with Leon, 95 YaLe L.J. 906 , 927-28 (1986).

31 See Donald Q. Cochran, Material Witness Detention in a Post-g/II World: Mission Creep or Fresh Start?, 8 Geo. MASON L. Rev. I, I 8 (20 I o) (describing the Bacon v. United States decision as the origins of probable cause standard for the elements of the material witness law).

32 Even at the point in America's history when an affiant's mere allegation that he had probable cause was sufficient for a warrant to issue, the affiant's failure to state the appropriate standard of suspicion he claimed to have would render the warrant invalid. See Oliver, supra note 29 , at $386-87$ (noting that in the mid-nineteenth century, an affiant's claim that he had "probable cause to suspect" fruits of a crime could be located in certain place, or that a person was guilty of crime, was insufficient; the affiant was required to allege that he had "probable cause to believe" the conclusion offered was true).

33 Mace Affidavit, supra note I 5 , at *64.

34 Remarkably, in Bacon v. United States, 449 F.2d 933, 943 (9th Cir. 1971), the Ninth Circuit held that when a witness is to be detained so that he may testify before a grand jury, the prosecutor's "mere statement" that the witness has material testimony is sufficient to issue the warrant for an arrest. 
to take a one-way, first class flight (costing approximately $\$ 5,000.00$ ) to Saudi Arabia on Sunday, March 16, 2003, at approximately 6:00 EST. He is scheduled to fly from Dulles International Airport to JFK International Airport in New York and then to Saudi Arabia." ${ }^{35}$ Al-Kidd actually held a round-trip coach-class ticket to Saudi Arabia that cost $\$ 1,700 .{ }^{36}$ No note was made of the fact that al-Kidd was an American-born citizen, not a Saudi national returning to his home country. ${ }^{37}$ The purpose of al-Kidd's travel to Saudi Arabia was to work on his doctorate in Islamic studies. ${ }^{38}$

Other omissions in the Mace Affidavit enhanced the false sense that was painted of al-Kidd. The affidavit failed to mention that al-Kidd had cooperated with all of the government's requests for information and had never failed to respond to a communication from any government agent. ${ }^{39}$ The affidavit failed to mention that no government agent had communicated with al-Kidd for six months before the request was made for his arrest warrant. ${ }^{40}$ No mention was made of the fact that no agent of the United States government had ever asked this cooperative American citizen to alert the government about overseas travel or to remain available in the country in the event that information he may have possessed became immediately important. ${ }^{41}$

Eight FBI agents seized al-Kidd in the Dulles International Airport on the material witness warrant. ${ }^{42}$ Agents interviewed him one to two hours after his arrest and told him that if he cooperated, "the matter might be resolved quickly and he could continue on his flight." ${ }^{43} \mathrm{He}$ agreed to talk and was asked about his religious faith, his conversion to Islam, and his travel plans. ${ }^{44}$ Much as he had done before, he answered all the questioned posed to him. ${ }^{45} \mathrm{He}$ was then held in Alexandria Detention Center in a high-security unit, reportedly in the same cells where John Walker Lindh and Zacarias Moussaoui had been held. ${ }^{46}$ Three days later, he appeared before a federal magistrate judge who recommended he waive a hearing until he could be transported back to Idaho, where "people were more

35 Mace Affidavit, supra note 15 , at *64.

36 First Amended Complaint and Demand for Jury Trial, supra note 14, at *25.

37 Id. at $* 16$.

38 Adam Liptak, Justices to Hear Appeal over Liability for Detention, N.Y. Times, Oct. I8, 2010, http://www.nytimes.com/2010/10/19/us/19scotus.html.

39 See First Amended Complaint and Demand for Jury Trial, supra note 14, at * I6.

40 Id.

4I Id. at *16-17.

42 Id. at *29.

43 Id. at * 30 .

44 Id.

45 Id.

46 Id. at *3I. 
familiar with his case." ${ }^{47} \mathrm{He}$ agreed with the judge's recommendation and two weeks of hell followed.

Despite assurances by the judge that he would be quickly transported back to Idaho, he was detained in Alexandria for nine more days ${ }^{48}$ While detained in Alexandria, he was held in single-person cell 22 to 23 hours a day, with a food slot providing him the only access to light outside his cell. ${ }^{49}$ Other inmates on this wing of the facility had glass plates on their cells, ${ }^{50}$ making their cells considerably less claustrophobic.

$\mathrm{He}$ was. then transported to a federal detention center aboard an aircraft designed for the transportation of high-risk prisoners. ${ }^{51}$ Once at the Oklahoma Federal Transfer Center, he was forced to sit naked, in view of other inmates who were being processed as well as male and female guards, before he was processed and given a cell in a high-security wing of the facility. ${ }^{52}$

The following day, he was placed on another similar flight to be transported to Boise, Idaho. ${ }^{53}$ Other prisoners on the flight were permitted to have their handcuffs loosened, but al-Kidd was not, even though this degree of restraint prevented him from using the restroom..$^{54}$ An officer on the flight explained that this would not be permitted because al-Kidd's case was "special." 55 Indeed his case was special. He may have been the only detainee on board who was neither convicted of, nor even charged with, a violation of any criminal ordinance. ${ }^{56}$

In Idaho, he met briefly with a federal public defender before an appearance before a federal magistrate. ${ }^{57}$ The government requested a three-day continuance and asked that bail be denied pending this continuance on the basis that al-Kidd was a flight risk and danger to the

47 Id. at * 32 .

$48 \mathrm{Id}$.

49 See id. at *31-32.

50 See id.

5 I See id. at *33-34. This method of transporting prisoners was made popular in the movie Con Air (Touchstone Pictures 1997), which was specifically mentioned in al-Kidd's Complaint. Id. at *33.

52 Id. at * 34 .

53. Id. at *35.

54 Id.

55 Id.

56 See id. at *34.

57 Id. at * 35 . 
community. ${ }^{58}$ The judge granted a two-day continuance and denied bail during this period..$^{59}$

Despite the precautions the government deemed necessary to prevent his escape or violence to the community, when al-Kidd's case was then heard sixteen days after his arrest, the judge released him with relatively few restrictions. ${ }^{60} \mathrm{He}$ was released into the custody of his wife, required to surrender his passport and regularly report to a probation officer. ${ }^{61}$ His travel was further restricted to four states. ${ }^{62}$

The government went to trial against Sami Omar al-Hussayen for the visa and misrepresentation charges as well as providing material support to a foreign terrorist organization; the latter charge was alleged in a superseding indictment following al-Kidd's arrest. ${ }^{63} \mathrm{Al}-$ Kidd was never subsequently interviewed about al-Hussayen, was never called to appear before a grand jury investigating al-Hussayen and was not called to testify at the criminal trial against al-Hussayen. ${ }^{64}$ A federal jury acquitted Sami Omar alHussayen of the material support charges and could not reach a verdict on the allegations of visa fraud and mis-statements to the government. ${ }^{65}$ The government decided not to retry him but never sought to end the restrictions placed on al-Kidd, who had cooperated whenever requested who had been treated like the worst of criminals. ${ }^{66} \mathrm{Al}-\mathrm{Kidd}$ told Adam Liptak of the New York Times that he had been detained in harsher conditions than anyone he encountered except one prisoner under sentence of death in Oklahoma. ${ }^{67}$

\section{The Rarely Used Federal Material Witness Statute}

From the very outset, for someone lacking extraordinary familiarity with the criminal justice system, even the authorization to arrest al-Kidd

58 Id. at ${ }^{*} 35-36$. The Bail Reform Act as codified in 18 U.S.C. $\$ 3143$ (2006) permits pretrial detention of suspects and witnesses on the basis of both flight risk and risk to the community. In United States v. Awadallah, 349 F.3d 42, 63 n.1 5 (2d Cir. 2003), the Second Circuit concluded in dicta that the risk to the community was an inappropriate basis for holding a material witness. As addressed infra note 74 and accompanying text, it is not clear why a prediction of future dangerousness is any more problematic as a basis for holding witnesses than it is as a basis for holding suspects.

59 First Amended Complaint and Demand for Jury Trial, supra note 14, at * 36.

60 See id. at *38.

$6 \mathrm{I} I d$.

62 Id.

63 See id. at *28, "38; see also Wadie E. Said, The Material Support Prosecution and Foreign Policy, 86 IND. L.J. 543, 581 (20I I) (describing al-Hussaven's prosecution).

64 First Amended Complaint and Demand for Jury Trial, supra note I4, at *38-39.

65 Id. at *38.

66 Id. at *38-39.

67 See Adam Liptak, Jailed as a Material Witness but Treated Like a Terrorist, a Laøsuit Says, N. Y. Times, Feb. 2 I, 201 I, at Ai 2. 
likely seems outrageous. At a basic level, the idea that a person can be held because he or she possesses information helpful to the government seems contrary to basic principles of our criminal justice system. For those with a somewhat more sophisticated understanding of the criminal justice system (or even the mental health system), the existence of such a statute may seem less problematic, even if this application seems like an absurdity.

The federal standard for arresting a material witness appears in the Bail Reform Act of 1984:

If it appears from an affidavit filed by a party that the restimony of a person is material in a criminal proceeding, and if it is shown that it may become impracticable to secure the presence of the person by subpoena, a judicial officer may order the arrest of the person... No material witness may be detained because of inability to comply with any condition of release if the testimony of such witness can adequately be secured by deposition, and if further detention is not necessary to prevent a failure of justice. Release of a material witness may be delayed for a reasonable period of time until the deposition of the witness can be taken pursuant to the Federal Rules of Criminal Procedure. ${ }^{68}$

The statute provides no opportunity for the witness to be heard before his arrest. Once he is arrested, the statute then directs the judicial officer to consider the terms of the witness's release, referring the judge to the statute relating to the "[r]elease or detention of a defendant pending trial." ${ }_{99}$ This provision requires the consideration of factors about a defendant's criminal history, employment, and ties to the community to determine the terms under which the defendant may be released, so that his presence at trial is ensured. ${ }^{70}$

These factors would also be relevant to determining how likely a witness is to appear for trial. The bail statute contains a controversial basis for detaining defendants pending trial, which seemingly would apply to witnesses as well. A judge is directed to determine the "condition or combination of conditions [that] will reasonably assure the appearance of the person in court and the safety of any other person and the community." 1 Using the possibility of a defendant's future violence to detain him pending trial was controversial when it was first implemented as a basis for holding those suspected of crimes. ${ }^{72}$ Uncharged conduct - even worse, conduct never committed - became a basis for detention when the Bail Reform

68 I 8 U.S.C. $\$ 3144$ (2006).

69 Id. $\$ 3142$.

70 See Marie VanNostrand \& Gena Keebler, Pretrial Risk Assessment in the Federal Court, 73 FED. Probation 3, 4-5 (2009) (discussing factors courts are to consider in evaluating conditions of release for individuals charged with a crime).

7 I Id. at 6.

72 See United States v. Salerno, 48I U.S. 739, 747-50 (1987); Judy Clarke, After Salerno: How to Avoid Pretrial Detention, Crim. Just., Fall 1987, at 20. 
Act was passed in $1984 .{ }^{73}$ The Material Witness Statute, by instructing a judge to consider the factors relevant to a criminal defendant's release, permits the detention of witnesses on the basis of predictions of their future dangerousness. ${ }^{74}$

The unusual nature of this power to detain witnesses is due in no small part to the fact that use of the power is unusual. It is very rarely used and typically only against foreign nationals in immigration cases where the government has a host of mechanisms for detaining the witness. ${ }^{75}$

The power of the government to hold individuals for reasons other than conviction of a crime is, however, not unique to material witnesses. A variety of societal interests permit detentions for reasons other than criminal punishment. Criminal suspects can, of course, be detained without a criminal conviction if no terms of their release can ensure that they will appear for trial, or if no terms of their release will ensure the safety of the public. ${ }^{76}$ The mentally disturbed who present a danger to themselves or others may be involuntarily committed. ${ }^{77}$ Those with certain communicable medical conditions may be quarantined against their will. ${ }^{78}$

73 See Albert W. Alschuler, Preventive Pretrial Detention and the Failure of Interest-Balancing Approaches to Due Process, 85 Mich. L. Rev. 510, 512 ( I986); Marc Miller \& Martin Guggenheim, Pretrial Detention and Punishment, 75 MinN. L. Rev. 335, 335 (I990); Michael Louis Corrado, Sex Offenders, Unlawful Combatants and Preventive Detention, 84 N.C. L. REv. 77, 85-87 (2005).

74 In Salerno, the Second Circuit held that future dangerousness was not an appropriate basis for detaining a material witness. Salerno, 48I U.S. at 744. The Supreme Court's decision affirming the constitutionality of future dangerousness as a basis for pretrial detention certainly did not consider material witnesses. The majority in Salemo reasoned that pretrial detention was not punishment at all and that predictions of future dangerousness were consistent with a variety of detentions, including the detention of the mentally disturbed. $I d$. at 746-47. Justice Marshall's dissent noted that the majority's reasoning authorizing preventive detention did not depend on a criminal charge at all. Id. at 763-64 (Marshall, J., dissenting).

75 Only $3.6 \%$ of all arrests by federal law enforcement officers were of material witnesses, and, of those, $92.3 \%$ were foreign nationals involved in smuggling aliens to delay their removal so they would be available to testify. Al-Kidd v. Ashcroft, 580 F.3d 949, 966 n. 16 (9th Cir. 2009).

76 Sex offenders may be confined at the end of their sentences if they present a risk of recidivism. See Kansas v. Hendricks, 52 I U.S. $346,350-58$ (1997) (rejecting due process challenge to civil commitment of sexual predators who pose danger to themselves or the community).

77 See Alexander Scherr, Daubert \& Danger: The "Fit" of Expert Predictions in Civil Commitments, 55 Hastings L.J. I, 29, 38 n. 192 (2003); Christopher Slobogin, An End to Insanity: Recasting the Role of Mental Disability in Criminal Cases, 86 VA. L. REv. I 199,1246 n. 172 (2000). But see O'Connor v. Donaldson, 422 U.S. 563, 575 (1975) (noting that involuntary confinement of a mentally ill person violates due process if the person poses no danger to himself or others).

78 See John Thomas Clarkson, Phase Six Pandemic: A Call to Re-evaluate Federal Quarantine Authority Before the Next Catastrophic Outbreak, 44 GA. L. Rev. 803, 8I6-I 7 (2010); Michelle A. Daubert, Pandemic Fears and Contemporary Quarantine: Protecting Liberty Through a Continuum of Due Process Rights, 54 Buff. L. Rev. I 299, 1353 (2007). 
The court's power to compel an unwilling witness to testify provides an even closer analogy to material witness detentions. ${ }^{79}$ Material witness detentions involve the government's power to hold a witness who prefers to prevent a court from hearing his testimony by being elsewhere when his testimony is required. Rarely does a court take the unusual step of ensuring the witness's presence by incarcerating him, because prosecutors infrequently request such detentions. Far more frequently a witness often a reporter - will comply with a subpoena but be unwilling to divulge requested information. In such cases, courts can, and frequently do, place the witness in jail until he or she cooperates. ${ }^{80}$

By contrast, material witness detentions provide the government a mechanism to ensure the testimony of those who attempt to avoid testifying by absenting themselves from the proceedings altogether. Conceptually, the existence of such a power is not as unusual as it may seem and has a long historical pedigree, even if it has been mostly a dormant power. ${ }^{81}$ Since the earliest days of the country's existence, Congress and many state legislatures have given courts the power to detain witnesses whose testimony is important to a criminal case if there are doubts about the willingness of the witness to voluntarily appear. ${ }^{82}$ Under federal law, if a judge is satisfied that a witness's testimony is "material" to a criminal prosecution and it would be "impracticable" to ensure the witness's presence by a subpoena, the witness may be placed under whatever degree of restraint the judge finds necessary to ensure his presence. ${ }^{83}$

Another use of this power was recently discovered, or to be more precise, re-discovered. ${ }^{84}$ Following the attacks of September 11, 2001, thenAttorney General John Ashcroft announced that the Justice Department would use material witness warrants to hold terrorist suspects when the government lacked adequate suspicion to charge them with crimes. ${ }^{85}$ It

79 See Sonja R. West, Awakening the Press Clause, 58 UCLA L. Rev. 1025, 1043-44 (201 I) (describing the circumstances under which reporters may be jailed for refusing to reveal their sources).

8o See RonNell Andersen Jones, Media Subpoenas: Impact, Perception and Legal Protection in the Changing World of American Journalism, 84 WASH. L. REv. 317, 34 I (2009) (observing the increased use of subpoenas for reporters in 2002).

81 See Stacey M. Studnicki \& John P. Apol, Witness Detention and Intimidation: The History and Future of Material Witness Law, 76 ST. JoHN's L. REv. 483, 487-92 (2002) (discussing the history of the material witness detention power).

82 See Stacey M. Studnicki, Material Witness Detention: Justice Served or Denied?, $4^{0}$ WAYNE L. Rev. I533, I 539-42 (1994) (describing history of material witness law in Michigan); Carolyn B. Ramsey, In the Sweat Box: A Historical Perspective on the Detention of Material Witnesses, 6 OHIO ST. J. CRIM. L. 68I, 690-92 (2009) (describing the history of material witness law in Illinois); Wesley MacNeil Oliver, The Rise and Fall of Material Witness Detention in Nineteenth Century New York, I N.Y.U. J.L. \& LiberTY 727 (2005) (describing New York's material witness law).

83 See 18 U.S.C. $\$ 3144$ (2006).

84 See infra note 205-06 and accompanying text.

85 This was part of a reorientation of the Department of Justice - the department's pri- 
seems to be beyond question that a material witness warrant was sought against al-Kidd because of the government's suspicions of his wrongdoing. In testimony before Congress, FBI Director Robert Mueller described the progress of his bureau after September $11{ }^{86} \mathrm{He}$ first described the arrest of Khalid Shaikh Mohammed, the alleged mastermind of the September 11 attacks. ${ }^{87}$ Abdullah al-Kidd was his second example followed by a number of defendants who had been arrested on criminal charges. ${ }^{88}$ Mueller never noted in his testimony that al-Kidd had been arrested as a witness against another, not as a suspect himself. ${ }^{89}$

Civil libertarians critical of many aspects of the Bush Administration's tactics in the new war on terror immediately objected that the Material Witness Statute was not intended as a means of preventive detention. ${ }^{90}$ Their arguments looked to the terms of the statute itself. The government's right to arrest a material witness is certainly triggered by his possession of information helpful to the government, not his criminal acts or anticipated criminal acts. The Administration's critics, however, never provided an answer to a difficult question raised by their thesis. Could the government be denied the right to hold a witness with information material to a criminal prosecution, whose presence could not be secured by subpoena, if the government also suspected the witness of wrongdoing himself? Does the government somehow have less ability to hold such a witness when the witness himself is also believed to be involved in acts that threaten widespread destruction?

mary goal was becoming preventing rather than punishing crime. Jules Lobel, The Preventive Paradigm and the Perils of Ad Hoc Balancing, 9I MiNn. L. Rev. I 407, 1408 (2007); U.S. DeP'T OF Justice, Shifting from Prosecution to Prevention, Redesigning the Justice Department to Prevent Future Acts of Terrorism (2002), available at http://www.justice.gov/archive/ag/ speeches/2002/fbireorganizationfactsheet.htm.

86 First Amended Complaint and Demand for Jury Trial, supra note 14, at *37.

87 Id.

88 Id. It seems doubtful Mueller was suggesting that al-Kidd was the second most important arrest in the War on Terror. It seems far more likely that al-Kidd's name was alphabetically the first in a list of persons deemed less significant than Khalid Shaik Mohammed. See Hearing on Departments of Commerce, Justice, and State, the Judiciary, and Related Agencies Appropriations for 2004, Part 6 Before the H. Comm. on Appropriations, 108th Cong. 9I (2003) (statement of Robert Mueller, Dir., FBI).

89 First Amended Complaint and Demand for Jury Trial, supra note 14, at *37.

90 See Nan Aron, Ashcroft v. al-Kidd: Immunity for the Shameless?, Huffington Post (Oct. 27, 2010), http://www.huffingtonpost.com/nan-aron/ashcroft-v-al-kidd-immuni_b_774604. html; Laurie Levenson, Detention, Material Witnesses \& the War on Terrorism, 35 Loy. L.A. L. REv. 121 7, 1 222-23 (2002) ("When America adopted into its laws the power to detain material witnesses, the focus of the law was on having an individual available to testify in a criminal proceeding."); Karen C. Tumlin, Suspect First: How Terrorism Policy Is Reshaping Immigration Policy, 92 Calif. L. Rev. I 1 73, 1200 (2004) (citing arguments that "the government has manipulated the material witness provisions, like the immigration statutes, to hold those it suspects of terrorist activities but for whom it does not have the probable cause necessary to support a criminal detention"). 


\section{Ninth Circuit Found Innocence a Pre-Requisite to Incarceration}

Abdullah al-Kidd's case presented the first opportunity to test the theory that material witness detentions could not be used to hold criminal suspects. Interestingly, the theory of recovery against John Ashcroft in his complaint was not based on the idea that pretextual uses of material witness detentions violate the Fourth Amendment. Al-Kidd contended in the complaint that John Ashcroft created a policy of using material witness detentions to hold suspects, which set in motion the actions of the FBI agents in this case to seek the detention of a "witness" whose potential testimony was not material and whose appearance could have easily been secured with a subpoena. ${ }^{91}$ Stated another way, al-Kidd contended that Ashcroft highly incentivized the use of material witness detentions as a means of holding suspects for whom the government lacked adequate suspicion to charge and then failed to ensure that prosecutors were only seeking to arrest those witnesses who fit the criteria of the Material Witness Statute. The Ninth Circuit used the case to announce a considerably more sweeping and specious proposition-that innocence is a pre-requisite to the detention of material witnesses. ${ }^{92}$

Al-Kidd brought a civil rights action against a number of people involved in his unfortunate detention, including those who filed the incomplete and false affidavits in support of his arrest warrant and those who determined that his degree of custody should be comparable to that of death-row inmates. ${ }^{93} \mathrm{He}$ also filed suit against then-Attorney General John Ashcroft, alleging that Ashcroft had set in motion a chain of events that allowed a perfectly law-abiding American citizen, indeed an all-American college football player, whose only sin appeared to have been his sincere conversion to Islam, to be treated like a hardened criminal. ${ }^{94}$ In the factual allegations in the complaint, al-Kidd stated that it was unreasonable to use a statute designed to ensure the presence of a witness to hold a suspect whom law enforcement officials lacked evidence to charge with a crime. ${ }^{95}$

91 First Amended Complaint and Demand for Jury Trial, supra note 14, at *39-41.

92 See Al-Kidd v. Ashcroft, 580 F.3d 949, 970 (2009).

93 See First Amended Complaint and Demand for Jury Trial, supra note I4, at * I 8-2 I (identifying parties).

94 Id. at *39-41, *44-50.

95 Id. at * $39-40$ ("[T] arrest and hold individuals whom the government lacked probable cause to charge with a crime but nonetheless wished to detain preventively and/or to investigate for possible criminal wrongdoing. . . Pursuant to this new, unlawful use of the Justice Department's material witness powers, Defendants' purpose in arresting and detaining Mr. al-Kidd was not to secure his testimony, but to preventively hold and investigate him for possible criminal wrongdoing. ..."). 
The portion of the complaint that stated claims for relief, however, had a somewhat narrower basis for relief (for violation of the Fourth Amendment):

Mr. al-Kidd's arrest, detention and post-release conditions violated the Fourth Amendment to the United States Constitution because, inter alia, (a) he was arrested for the unlawful purpose of detaining him preventively and/or for further investigation, and not because his testimony was needed; (b) because there was no probable cause to believe his testimony could not be secured without arrest; (c) because there was no probable cause to believe $\mathrm{Mr}$. al-Kidd had testimony germane to a criminal proceeding; (d) because of the prolonged, excessive, and punitive conditions of Mr. al-Kidd's detention and postrelease terms; and (e) because of Defendants' unreasonable and unlawful searches, including strip searches. ${ }^{96}$

Al-Kidd offered a nearly identical claim against the various defendants in this case for violating the terms of Material Witness Statute:

Mr. al-Kidd's arrest, detention and post-detention release conditions violated the Material Witness Statute because, inter alia, (a) he was arrested for the unlawful purpose of detaining him preventively and/or for further investigation, and not because his testimony was needed; (b) because there was no probable cause to believe his testimony could not be secured without arrest; (c) because there was no probable cause to believe $\mathrm{Mr}$. al-Kidd had testimony germane to a criminal proceeding; and (d) because of the prolonged, excessive, and punitive conditions of Mr. al-Kidd's detention and post-release terms. ${ }^{97}$

Al-Kidd's claim was, in essence, that Ashcroft created conditions that were ripe for "witnesses" whom the government suspected of terrorist activities to be detained even though the conditions of the Material Witness Statute were not satisfied. Al-Kidd contended that Ashcroft's "unlawful" policy of using material witness detentions to hold suspects created this risk. ${ }^{98}$ The separate counts in the complaint seemed to do no more than offer different authority to demonstrate why the actions of the former Attorney General were illegal.

The district court held that on the basis of the pleadings, Ashcroft was not entitled to absolute or qualified immunity. ${ }^{99}$ Its memorandum order stated al-Kidd's basis for Ashcroft's liability as follows:

\footnotetext{
96 Id. at * 52 .
}

97 ld. at *51-52.

98 Even though the Supreme Court ultimately ruled that the pretextual use of material witness detentions did not violate the Fourth Amendment, it seems that al-Kidd's argument that Ashcroft failed to take measures to ensure witnesses were not detained without a sufficient basis survived the Supreme Court's decision. See discussion at infra note 188-95 and accompanying text.

99 Memorandum Order, Ashcroft v. Gonzales, 2006 WL 5429570, at *9. 
[T]he claims against Mr. Ashcroft contend that he spear-headed the post-September 11, 2001 practice of the Department of Justice to use the material witness statute to detain individuals whom they sought to investigate but had not charged with a crime. ${ }^{100}$

The debate in the trial court focused on whether al-Kidd had sufficiently made a claim for which Ashcroft bore responsibility for a warrant being issued for his arrest when neither the materiality of al-Kidd's testimony nor his feared unavailability for trial had been demonstrated in the application for the warrant. ${ }^{101}$ The Supreme Court's decision in Ashcroft v. Iqbal requires more than an allegation that a government official had a supervisory role over an offending official to be liable. ${ }^{102}$ One of the most difficult hurdles al-Kidd faced was demonstrating a sufficient, causal link between the wholly inadequate application for alKidd's arrest and the policies of Ashcroft under the Iqbal standard. The Justice Department argued in the district court that "the vague and conclusory allegations in the complaint allege nothing more than a claim against Mr. Ashcroft based upon his supervisory status but not upon his actual personal involvement." 103 The district court found the complaint "sufficient . . . to raise a claim for relief against Mr. Ashcroft as to his involvement in the constitutional violations allegedly incurred by $\mathrm{Mr}$. al-Kidd." ${ }^{04}$ The district court did not even address the pretext issue that took this case to the Supreme Court, namely that Ashcroft could be liable for damages if the facts alleged in the Mace Affidavit were sufficient for a material witness warrant.

Like the district court, the Ninth Circuit found that this was a valid claim against Ashcroft. ${ }^{105}$ The court recognized that two recent Supreme Court cases, Bell Atlantic Co. v. Twombly and Ashcroft v. Iqbal, required some degree of specificity in the allegation that Ashcroft had a role in a warrant being sought when the requirements for such warrants had not been satisfied. ${ }^{106}$ The court found that al-Kidd offered more than "bare allegations" that Ashcroft layed role in his allegedly baseless arrest. ${ }^{107} \mathrm{Al}-$ Kidd asserted in his complaint that Ashcroft made statements concluding that the "[a]ggressive detention of . . . material witnesses [was] vital to

100 Id. at.* 4 .

I0I Id. at *9 ("Mr. al-Kidd's allegations are that probable cause as not shown in the warrant application and, therefore, his constitutional rights were violated.").

102 See Arthur R. Miller, From Conley to Twombly to Iqbal: A Double Play on the Federal Rules of Civil Procedure, 60 Duke L.J, I, I9(2010).

I03 Memorandum Order, supra note 99 , at * 9 .

104 Id.

105 Al-Kidd v. Ashcroft, 58o F.3d 949, 98 I (9th Cir. 2009).

I 06 Id. at $974-77$.

I07 Id. at 975. 
preventing, disrupting or delaying new attacks." ${ }^{108}$ Al-Kidd alleged that nearly $50 \%$ of those detained as witnesses in the wake of September 11 were never called to testify. ${ }^{109}$ Finally, al-Kidd alleged that the attorney general should have been on notice of detentions of persons who did not satisfy the statutory requirements because of extensive media coverage of abuses of the Material Witness Statute following September 11. ${ }^{110}$ The court found that this claim stated a cause of action against Ashcroft "independent of the constitutionality of [the Material Witness Statute] for investigatory purposes ...."111

The court also concluded that al-Kidd raised a much more abstract claim, the claim that ultimately found its way to the Supreme Court. In his brief to the Ninth Circuit, Ashcroft argued that his policy on material witness detentions could not be unconstitutional as any material witness arrest that satisfied the terms of the statute was objectively reasonable. ${ }^{112}$ Represented by the Justice Department, he contended that, "[e]ven if former Attorney General Ashcroft instituted a policy requiring the pretextual use of material witness warrants to investigate terrorist suspects, as plaintiff alleges, the subjective motivation alleged does not render the policy unconstitutional[.]"113

Al-Kidd's response to Ashcroft's argument reframed the issue the Ninth Circuit was considering. To negate Ashcroft's argument that his policies were irrelevant, al-Kidd made a very broad claim that the Ninth Circuir would embrace without qualification:

If defendant's policy were upheld, it would allow the government to do an end-run around the Fourth Amendment. Rather than arresting an individual only after an investigation has established probable cause of criminal wrongdoing, the government would now be able to arrest that individual and then investigate for possible criminal wrongdoing. ${ }^{114}$

The Ninth Circuit then characterized al-Kidd's Fourth Amendment claim in the following terms:

[A]l-Kidd alleges that Ashcroft designed and implemented a policy under which the FBI and DOJ would arrest individuals who may have met the facial statutory requirements of [the

I08 Id. (quoting John Ashcroft, Attorney General, Attomey General Ashcroft Outlines Foreign Terrorist Tracking Task Force (Oct. 3I, 200I), available at http://www.usog.gov/archive/ag/ speeches/201 1/agcrisisremarks Io_3 3 .htm).

109 Id.

110 Id. at 976.

I I Id. at 973 .

I 2 Appellee's Opposition Brief, at 2 I, al-Kidd, 580 F.3d 949 (No. 06-36059), 2007 WL 2063598.

I $13 \mathrm{ld}$.

I 14 ld. at *22. 
Material Witness Statute], but with the ulterior and allegedly unconstitutional purpose of investigating or preemptively detaining them, in violation of the Fourth Amendment .... ${ }^{115}$

Addressing this issue, Ashcroft claimed material witness detentions should be viewed like any other arrest based on probable cause. ${ }^{116}$ Whren $v$. United States, the paradigm case Ashcroft offered, held that an officer's basis for stopping a motorist was irrelevant so long as there was probable cause to believe the motorist had committed a traffic offense. ${ }^{117} \mathrm{Al}$-Kidd contended that the reason for a seizure was relevant whenever the government did not have an articulable basis for suspecting criminal wrongdoing. ${ }^{118}$ City of Indianapolis $v$. Edmond, the paradigm case al-Kidd offered, held that cars could not be randomly seized at a roadblock to check for drugs. ${ }^{119}$ The Ninth Circuit would find that Edmond controlled. ${ }^{120}$ The Supreme Court would reverse, finding that Whren controlled. ${ }^{121}$ The facts of al-Kidd, however, neatly fit within neither paradigm.

Most often, as long as there is a legitimate basis for a search or seizure, the real reason the government agent acted is irrelevant. ${ }^{122}$ Minor speeders, for instance, can be stopped amid of sea of reckless drivers even if the officer's motivation for the stop was an unsupportable hunch that the driver was transporting drugs. In the traffic stop example, however, several motorists were guilty of criminal wrongdoing, admittedly in varying degrees. ${ }^{123}$ Once there is an adequate factual basis to believe that a particular individual has engaged in wrongdoing, it does not matter that the government acted because it suspected more serious wrongdoing but lacked the evidence to demonstrate it. ${ }^{124}$ Of course detaining someone the government suspected of terrorism does not easily fit into this paradigm. There is nothing inherently wrong about possessing information helpful to the government, even in a terrorism prosecution.

The Ninth Circuit therefore drew on a different line of Fourth Amendment cases. The government is allowed to engage in certain types of searches or seizures of persons whom it has no basis to suspect of

I 5 al-Kidd, 580 F.3d at 957 .

I 6 See id. at 966.

117 Whren v. United States, 5 I 7 U.S. 806, 8 I I (1996).

1 I 8 See al-Kidd, 580 F.3d at 968.

I I9 Id. at 968-69 (citing City of Indianapolis v. Edmond, 53 I U.S. 32, 45-47 (2000)).

120 al-Kidd, 580 F.3d at 968.

121 Ashcroft v. al-Kidd, I31 S. Ct. 2074, 2082 (201 1).

122 United States v. Knights, 534 U.S. 112, I 22 (2001) ("With the limited exception of some special needs and administrative search cases, "[the Court] ha[s] been unwilling to entertain Fourth Amendment challenges based on the actual motivations of individual officers." (citation omitted) (quoting Whren, 517 U.S. at $\left.8 I_{3}\right)$ ).

123 See Whren, 517 U.S. at 818-19.

124 See id. 
criminal activity, so long as the real reason for the seizure is not to explore the possibility of criminal activity. Often these searches are identified as "special needs" searches or seizures, where the purpose of the government's action is something "other than that of traditional law enforcement." 25 Motives matter in this line of cases. Roadblocks that stop every driver, ${ }^{126}$ or every tenth driver, ${ }^{127}$ are permitted to ensure that motorists are insured, ${ }^{128}$ so long as the actual purpose is not to run a dog around the car to check if the motorist is transporting drugs. ${ }^{129}$ Such roadblocks are acceptable to protect highways from drunk drivers or to ensure that all motorists are licensed. ${ }^{130}$ Railroad workers can be randomly drug tested if the motives of the investigators are to ensure the safety of the railroad, but not if their purpose is to investigate the crime of drug possession. ${ }^{131}$

The "special needs" cases similarly do not provide a ready analogy to the detention of material witnesses. The witness's seizure and detention is far from random. The witness is uniquely identified because of information he possesses, yet his possession of the material information does not equate to wrongdoing. Does the government's selection process that uniquely identifies a specific person to be detained for a legitimate reason other than criminal investigation make the government's use of this device to investigate crime irrelevant? Or must there be evidence providing probable cause of guilt before the government's motivation becomes irrelevant?

The Ninth Circuit found witness detentions to be more analogous to special needs seizures and held that to seize a witness without suspicion of wrongdoing the purpose must be for something other than pursuing a criminal case against him. ${ }^{132}$ The court found that material witness detentions for the purpose of holding criminal suspects bypassed the

I 25 Ric Simmons, Search for Terrorists: Why Public Safety is Not a Special Need, 59 Duke L.J. $843,889-90$ (2010).

I 26 See Delaware v. Prouse, 440 U.S. 648, 656-58 (1979) ("For Fourth Amendment purposes, [the Court saw] insufficient resemblance between sporadic and random stops of individual vehicles making their way through city traffic and those stops occasioned by roadblocks where all vehicles are brought to a halt...." (emphasis added)).

I 27 See id. at 664 (Blackmun, J., concurring) ("The roadblock stop for all traffic is given as an example [by the majority]. I necessarily assume that the Court's reservation also includes other not purely random stops (such as every Ioth car to pass a given point) that equate with, but are less intrusive than, a $100 \%$ roadblock stop.").

128 See id. at 657-59 (majority opinion).

129 City of Indianapolis v. Edmond, 53 I U.S. 32, 40-42 (2000) ("The fact that officers walk a narcotics-detection dog around the exterior of each car at the Indianapolis checkpoints does not transform the seizure into a search," but "[b]ecause the primary purpose of the Indianapolis narcotics checkpoint program is to uncover evidence of ordinary criminal wrongdoing, the program contravenes the Fourth Amendment." (emphasis added)).

I30 See Prouse, 440 U.S. at 657-58.

I3I See Skinner v. Ry. Labor Execs. Ass'n, 489 U.S. 602, 620-2 I (I989).

132 Al-Kidd v. Ashcroft, 58o F.3d 949, 970 (9th Cir. 2009). 
Fourth Amendment's requirement that the government have probable cause to seize and hold a criminal suspect. ${ }^{133}$

The Ninth Circuit made a choice between two competing paradigms of legal authority, neither of which provided a complete analogy to the power of the government to arrest witnesses. Ashcroft argued that under Whren, "[s]ubjective intentions play no role in ordinary, probable-cause Fourth Amendment analysis." ${ }^{134}$ The Ninth Circuit quite correctly observed that the issue was far more complicated than Ashcroft suggested. "[A]rrests of material witnesses are neither 'ordinary,' nor involve 'probable cause' as that term has historically been understood," Judge Milam Smith concluded. ${ }^{135}$ "Whren rejected only the proposition that 'ulterior motives can invalidate police conduct that is justifiable on the basis of probable cause to believe that a violation of law has occurred." 136

The Court reasoned that if the arrest is objectively justified by evidence of the detainee's wrongdoing, then the actual reason for the seizure is irrelevant. ${ }^{137}$ If, however, the government offers a basis other than the detainee's wrongdoing for seizing him, then the government's motive for seizing him is relevant. ${ }^{138}$ Once it decided that material witness detentions fit better within the "special needs" line of cases, the Ninth Circuit mechanically applied the Supreme Court's precedent to conclude that the government's interest in conducting a criminal investigation negated the legitimacy of the detention. ${ }^{139}$ In the view of the Ninth Circuit, al-Kidd had adequately alleged that the purpose of this detention was a criminal investigation and the seizure, justified on a basis other than al-Kidd's wrongdoing, violated the Fourth Amendment. ${ }^{140}$

Viewing the legal doctrines in isolation, the Ninth Circuit's conclusion seems to have been one of two reasonable paths before it. A strong argument can indeed be made that the Ninth Circuit picked the more analogous strain of authority. Looking at the practical impact of choosing the Ninth Circuit's path makes its choice considerably more questionable. Regardless of whether the government suspected the witness of criminal activity, his detention was bypassing any consideration of whether there was probable cause of his wrongdoing. Typically, the government's "special need" permits only minor intrusions - certainly when the intrusion is a seizure of the person. The Supreme Court noted that seizures at roadblocks involved

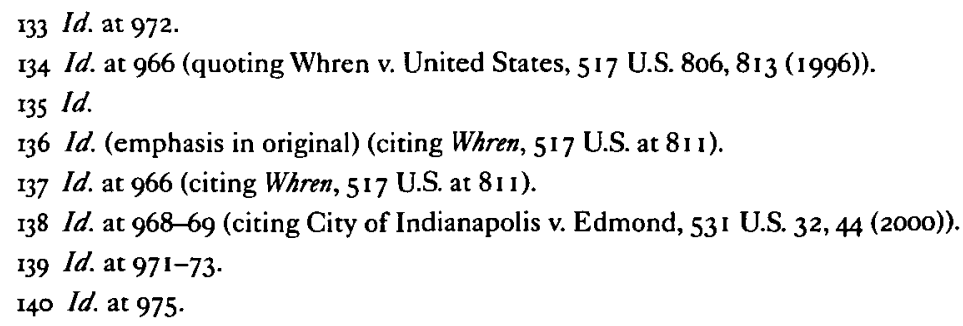


a "brief" and "slight" intrusion. ${ }^{141}$ The Court has recognized that the government's interest in officer safety permits officers to order passengers out of stopped automobiles, but the Court observed that the intrusion was "de minimis." 142 The Supreme Court has recognized that, by contrast, arrests are substantial intrusions. ${ }^{143}$ The facts of al-Kidd's case certainly do nothing to undermine this conclusion. Either the Ninth Circuit was giving the government considerable power to impose on its citizens once a "special need" was demonstrated, or it left out a very substantial part of its conclusions. If the interest in securing witnesses is viewed like other special needs, then only a de minimis intrusion on a citizen's liberty is permitted to vindicate it.

On a more practical level, choosing the line of authority that made the government's motivation for the detention relevant left a very puzzling result. A witness the government suspected of no wrongdoing could be detained. A witness the government suspected of membership in al-Qaeda must be left at large until adequate suspicion existed to charge him with a crime. Innocence was thus a pre-requisite to arrest and detention as a material witness.

The difficulty with the Ninth Circuit's analysis did not end there. As this was a civil rights action against John Ashcroft in his individual capacity, alKidd faced another hurdle. He was required to show that the constitutional prohibition on using material witness detentions to hold criminal suspects was "clearly established." To ensure that government actors are not afraid to do their jobs, federal civil rights laws have long provided that officials are only civilly liable for actions that they should be aware violate either constitutional or statutory provisions. ${ }^{144}$ The Ninth Circuit offered two separate justifications for its conclusion that Ashcroft should have been aware that this use of the federal material witness detention statute violated the Fourth Amendment.

First, the court opined, it was patently obvious that the statute was not intended to be used as a mechanism to hold suspects. ${ }^{145}$ No case at the time the warrant was issued in this case had found that such use of the material witness detention statute was contrary to the Fourth Amendment, but the court reasoned that no court would have had an opportunity to rule on such use of the detentions. ${ }^{146}$ Without offering any citation, the court made the remarkable (and incorrect) historical claim that such use of the detentions

I4I Mich. Dep't of State Police v. Sitz, 496 U.S. 444, 45 I-52 (1990).

142 Maryland v. Wilson, 5 I9 U.S. 408, 412 (1997).

I43 Payton v. New York, 445 U.S. 573, 58I ( I 980).

I44 See John C. Jeffries, Jr., Disaggregating Constitutional Torts, i 10 Yale L.J. 259, 269-70 (2000) (explaining basis for qualified immunity is fear of over-deterrence).

I45 al-Kidd, 580 F.3d at $965-67$.

I46 Id. at $970-7$ I. 
was so patently contrary to the Constitution that the detentions of suspects under Material Witness Statutes had never previously been attempted. ${ }^{147}$

Even without historical evidence to the contrary, it would be hard to accept the court's conclusion that no governmental actor prior to Ashcroft had discovered that Material Witness Statutes provided a mechanism to detain a suspect while a case was worked up against him. ${ }^{148}$ But historical evidence to the contrary abounded and the Ninth Circuit was aware of it. ${ }^{149}$ The court cited to this author's work on the history of material witness detentions for the proposition that material witness detentions began to occur only in the $1840 \mathrm{~s} .{ }^{150}$ The court then missed the main thrust of the article it cited: That material witness detentions have always been used to hold suspects prosecutors lacked adequate suspicion to charge.

Historical acceptance of material witness detentions actually depended on them being used in the manner the Ninth Circuit found to be clearly unconstitutional. ${ }^{151}$ While material witness detentions occur very infrequently in modern times, they were quite common in a number of American cities in the late nineteenth and early twentieth centuries. ${ }^{152}$ Objections were made to the practice in general and to the detention of innocent bystanders in particular - exactly the type of witnesses the Ninth Circuit found it constitutionally acceptable to detain.

The practice of detaining witnesses occurred so frequently between 1850 and 1930 as to provide a very complete picture of the reasons for the detentions and the public's acceptance of the practice. In New York City, the practice was so common that high-profile public figures and interest groups came to publicly oppose the practice over several decades, prompting a series of reforms. ${ }^{153}$ A substantial piece of evidence demonstrating the frequency of this practice is seen in the facility holding witnesses. In 1857 , the City created a separate facility, the House of Detention for Witnesses,

147 Id. at 970 .

I48 See Donald Q. Cochran, Material Witness Detention in a Post-g/Ir World: Mission Creep or Fresh Start?, I8 Geo. Mason L. Rev. I, I5 (2010) ("As to the allegation that the line between witness and suspect has been blurred by post-9/1 I policy, it is not at all clear that such a line ever existed or should exist."). A number of academic commentators in the wake of September I I concluded that the material witness detention statute could not be used to hold criminal suspects. See, e.g., Ronald L. Carlson, Distorting Due Process for Noble Purposes: The Emasculation of America's Material Witness Laws, 42 GA. L. REv. 94 I, 972 (2008); see also sources cited at supra note 75 .

149 al-Kidd, 580 F.3d at 959.

150 Id. (citing Oliver, supra note 82).

151 See Brief of Amicus Curiae Wesley MacNeil Oliver in Support of the Petitioner at 4-5, Ashcroft v. al-Kidd, I 3 I S. Ct. 2074 (20 I I) (No. I0-98), 20 I0 WL 5125442. 152 See Oliver, supra note 82, at 728 n. I; Carolyn B. Ramsey, In the Seceat Box: A Historical Perspective on the Detention of Material Witnesses, 6 OHIO ST. J. CRIM. L. 68I, 708-09 (2009).

${ }_{53}$ Oliver, supra note 82 , at 780 . 
so that those held would not languish in the same condition as pre-trial detainees and convicted misdemeanants. ${ }^{154}$

The conditions of confinement had not been the sole, or even primary, concern of reformers who objected to the practice of material witness detentions in the second half of the nineteenth century. ${ }^{155}$ While many reformers thought that the possession of information helpful to a prosecution should not provide a legal basis for detaining anyone; all reformers focused on tales of innocent persons held to testify against criminal suspects. ${ }^{156}$ Some reformers even expressly recognized that their concern was for the bystander alone, and they would permit the detentions of those "witnesses" suspected of involvement with the defendant against whom they were held to testify. ${ }^{157}$

A cartoon from Harper's Weekly from 1881 clearly demonstrates the primary concern of those reformers in New York who fought to end, or at least limit, the power of the state to hold witnesses. ${ }^{158}$ The cartoon shows an innocent witness in the House of Detention for Witnesses while the defendant against whom he is to testify is in a tavern boastfully displaying a paper reporting that he is out on bond. By 1883, New York revised its law relating to material witnesses, limiting the power of magistrates to order the detention of those witnesses suspected of complicity in the crimes about which they allegedly had information. ${ }^{159}$ The number of persons held in the House of Detention for Witnesses did not precipitously.drop after the legislature permitted only the detention of suspect-witnesses, revealing that a considerable number of those witnesses detained prior to 1883 were also suspected of criminal activity. ${ }^{160}$

154 See id. at 753-54.

155 See Brief of Amicus Curiae Wesley MacNeil Oliver, supra note 150, at 7-8 (arguing that innocent detainees were the primary concern of reformers).

156 Id. at 7 .

157 See Oliver, supra note 82, at 744-45.

${ }_{15} 8 \mathrm{Id}$. at 778 .

159 See id. at 779 .

I60 Id. at $76 \mathrm{I}-62$ (showing that detentions numbered 408 in 1882,228 in 1883,286 in I884, and 328 in 1885 ). 


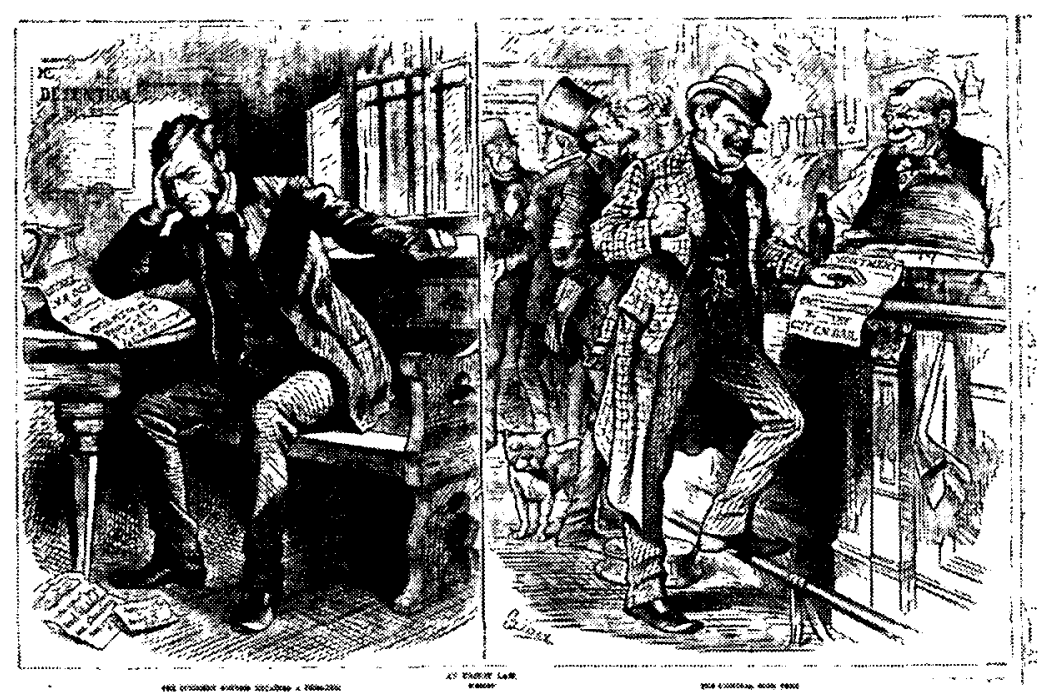

Figure One. An Unjust Law. Harper's Weekly, April 9, 1881 at 228. The caption notes "The Innocent Witness Detained as a Prisoner, whilst the Criminal Goes Free."

The unique concern for innocent detainees continued into the twentieth century. After New York dropped its requirement that detained witnesses also be suspected of wrongdoing themselves, an association of grand jurors in 1930 complained about the treatment of innocent detainees. ${ }^{161}$ The group expressly noted that it felt no sympathy with those somehow involved with defendants, even if the witness was merely suspected of being a member of the same criminal organization as the defendant against whom he was to testify. ${ }^{162}$

The Ninth Circuit's reliance on history was thus backwards in two important respects. Not only were material witnesses used as a pretext to hold suspects prior to September 11,2001, historically this appears to have been the most frequent use of such detentions. Additionally, the public was very much aware of, and indeed most tolerant of, this pretextual use of the power to hold material witnesses. The Ninth Circuit concluded that no prosecutor would have considered using material witness detentions to hold suspects prior to September 11 because such use was universally regarded as unreasonable. The reality is that historically the use of material witness detentions to hold anyone other than a suspect as a material witness was widely regarded as unreasonable and, for a twenty-year period, was contrary to a New York statute.

I6I See Brief of Amicus Curiae Wesley MacNeil Oliver, supra note 151, at 19-20. I62 See id. at 20. 
Because of the history prompting the Fourth Amendment itself, the Ninth Circuit further concluded Ashcroft was on notice that he violated the Fourth Amendment by detaining someone he suspected of terrorist activity as a witness. ${ }^{163}$ In its opinion, the court offered a brief recitation of the events commonly believed to have motivated the Framers of the Fourth Amendment to draft this provision of the Bill of Rights. ${ }^{164}$ It recounted British outrage at the issuance of warrants that permitted officers to search anywhere they chose to discover the authorship of papers libeling one of the king's ministers. ${ }^{165}$ This history, the Ninth Circuit concluded, should have put Ashcroft on notice that circumventing the probable cause requirement to arrest a criminal suspect violated the Fourth Amendment. ${ }^{166} \mathrm{It}$ is difficult to see what this particular history adds to the probable cause requirement in the amendment itself. Justice Scalia's opinion for the Supreme Court dispensed with the Ninth Circuit's attempt at this historical analogy with his characteristically sarcastic pith: "Ashcroft must be forgiven for missing the parallel, which escapes us as well." 167

\section{Correcting a Glear Error}

The United States Supreme Court in Ashcroft v. al-Kidd was in a position in which it rarely finds itself, sitting as a Court for the correction of errors. There was no circuit split on the limits of the government's subjective intent in its use of material witness detentions.

Doctrinally, al-Kidd did not present an easy case; practically, it could not have gone any other way. Prior to $a l-K i d d$, the government's motive for suspicionless intrusions for purposes other than the enforcement of criminal law was relevant to assessing the legitimacy of the intrusion. Once the government had adequate suspicion to justify a search or seizure to investigate criminal wrongdoing, or to seize the defendant to commence a prosecution, the "real" reason for the government's action became irrelevant. Al-Kidd's facts placed it between the strains of existing authority. Precedent did not resolve whether the government's motive mattered when it sought to arrest an individual based on information unrelated to his criminal wrongdoing but nevertheless specific to the arrestee. Prior to al-Kidd, it was far from clear whether an individualized basis for suspecting criminal wrongdoing, or merely individual consideration of any factors justifying a search or seizure made the government actor's "real" motives irrelevant.

r63 Al-Kidd v. Ashcroft, 580 F.3d 949, 97I (9th Cir. 2009).

I64 Id. at 972.

I65 Id.

I66 Id. at $972-73$.

I67 Ashcroft v. al-Kidd, 131 S. Ct. 2074, 2084 (201 1). 
The practical consequences of doing anything but reversing were illustrated by the Ninth Circuit's bottom line. Innocent bystanders could be detained more readily than terrorist suspects whom the government barely lacked suspicion to charge. The purpose of a Material Witness Statute is surely not to create a scheme of preventive detention, ${ }^{168}$ but there would be something quite odd about interpreting the statute to prevent a mixed motive detention. The absence of suspicion obviously should not be a basis for more readily detaining a witness. Further, witnesses with information helpful to the prosecution in a criminal matter are often in positions that would make the government suspect them of criminal involvement. If the government could detain only those whom it suspected of nothing, or demonstrate that it had no interest in prosecuting those whose testimony it sought, this would substantially limit the usefulness of the statute.

Unsurprisingly, the majority's opinion was written by Justice Scalia. He authored the Court's unanimous decision in Whren $v$. United States upon which Ashcroft principally relied. Weaknesses in Scalia's opinion reveal how poorly this case mapped onto any existing line of Fourth Amendment precedent.

Justice Scalia reasoned that there were "two limited exceptions" to the general rule that the motivations of government actors are irrelevant for Fourth mendment purposes. ${ }^{169}$ These exceptions are "special needs" and administrative searches and seizures. ${ }^{170}$ By Scalia's own reasoning, however, these exceptions are not so neatly defined as to exclude the government's interest in ensuring a witness's presence at trial. ${ }^{171}$ Further, Justice Scalia recognized that these were not the only types of exceptions but made no effort to exhaustively account for the other exceptions. ${ }^{172}$

Special needs searches, according to his opinion, are justified by a government interest "beyond the normal need for law enforcement." ${ }^{173}$

I68 As David Cole has noted, however, the United States has a scheme of preventive detention, though the purpose of such a scheme is not expressly recognized. Material witness detentions are part of this scheme. David Cole, Out of the Shadows: Preventive Detention, Suspected Terrorists, and.War, 97 CALIF. L. REv. 693, 722-25 (2009).

I69 al-Kidd, I3I S. C. at 2080-8I.

170 Id.

I7I The poorly defined quality of the category of "special needs" exceptions has been frequently observed. E.g., Eva Brensike Primus, Disentangling Administrative Searches, I I 1 Colum. L. Rev. 254, 257 (2011) ("[S]cholars and courts find it difficult to even define what an administrative search is, let alone to explain what test governs the validity of such a search."); Jonathan Kravis, A Better Interpretation of "Special Needs" Doctrine After Edmond and Ferguson, I 2 YALE L.J. 2591, 2594-95 (2003).

172 al-Kidd, ${ }_{13}$ I S. Ct. at 2081 ("The Government seeks to justify the present arrest on the basis of a properly issued judicial warrant-so that the special-needs and administrative-inspection cases cannot be the basis for a purpose inquiry here. Apart from those cases, we have almost uniformly rejected invitations to probe subjective intent." (emphasis added)).

I73 al-Kidd, I 3 I S. Ct. at 208 I; see Griffin v. Wisconsin, 483 U.S. 868, 873 ( 1987 ) (Blackmun, J., concurring) (citing New Jersey v. T.L.O., 469 U.S. 325, 35 I (1985)). 
His separate category of administrative searches occur when a "search or seizure is in execution of an administrative warrant," as when a warrant permits inspectors to ensure compliance with housing codes. ${ }^{174}$. It is not entirely apparent that these are necessarily separate categories. The exception for searches or seizures in either of these categories seems to rest on the proposition that government intrusions for purposes other than the enforcement of criminal laws may proceed with less stringent prerequisites, both substantively (i.e., something less than probable cause) and procedurally (i.e., without a judicial warrant). ${ }^{175}$ It is possible to delineate these two separate categories of special needs searches and administrative searches, but the distinction has little substantive difference. Both permit the government to justify a search or seizure without demonstrating probable cause to a judicial officer. ${ }^{176}$

Finally, the opinion recognized that there were other categories of searches and seizures, other than "special needs" and administrative intrusions, for which the motives for the intrusion were relevant.

\begin{abstract}
Apart from those cases, we have almost uniformly rejected invitations to probe subjective intent.... There is one category of exception, upon which the Court of Appeals principally relied. In Edmond, . . . we held that the Fourth Amendment could not condone suspicionless vehicle checkpoints set up for the purpose of detecting illegal narcotics. ${ }^{177}$
\end{abstract}

Just as it is not clear how there are different justifications for the administrative warrant and "special needs" exceptions to the Fourth Amendment's baseline requirements, it is not clear how drug roadblocks constitute a different "category of exception." ${ }^{178}$ It is not clear that drug roadblocks are an exception to the Fourth Amendment's baseline requirements at all. Most scholars regard drug roadblocks as simply not fitting into an exception, as a drug roadblock is not performed to vindicate an interest beyond the normal need for law enforcement. ${ }^{179}$ As Scalia described in the opinion, "we found the drug-detection purpose in Edmond

174 al-Kidd, 131 S. Ct. at $208 \mathrm{I}$.

175 See Craig S. Lerner, The Reasonableness of Probable Cause, 81 Tex. L. Rev. 951, 100310 (2003) (discussing the lower evidentiary standard required by courts for "special needs" searches).

176 See Simmons, supra note 125 , at 848 (referring to all such searches as "permissible suspicionless searches").

I77 al-Kidd, 13 I S. Ct. at $208 \mathrm{r}$.

I78 Roadblocks have, for instance, been described by some scholars as administrative searches and by others as "special needs" searches. See Michael R. Dimino, Sr., Police Paternalism: Community Caretaking, Assistance Searches, and Fourth Amendment Reasonableness, 66 WASH. \& LeE L. Rev. 1485, 1522 (2009) (describing the "Court's 'special needs' precedents involving roadblocks and inventory searches....") (footnotes omitted); Primus, supra note 170 , at 292-93 (describing roadblocks as administrative searches).

I79 See Simmons, supra note 125 , at 871-73. 
invalidating because it was "ultimately indistinguishable from the general interest in crime control." 180

If roadblocks, which do require an inquiry into the government's motives, belong in a "category of exceptions," beyond administrative and "special needs" searches, requiring an analysis of the government's motives, are there other categories? And how would the court deal with these other exceptional circumstances for which the motives of government actors matter? Could there be another category of exception - perhaps an administration of justice exception - which allows courts to subpoena and detain witnesses? As Justice Scalia offered no single explanation for the categories of cases requiring the government to have a pure motive, his admittedly less than exhaustive accounting of the "categories of exceptions" left a hole in his argument. To have acknowledged that under existing doctrine, motives matter whenever the government acts without suspicion of wrongdoing would have required Scalia to acknowledge he was creating new law. Concluding that material witness detentions did not fit into any recognized exception to the general prohibition on considering a government actor's motive allowed Scalia's opinion to appear to be a formalistic application of fact to rule rather than a choice of precedent driven by policy considerations. ${ }^{181}$

The opinion would further (and falsely) lead a reasonable reader to conclude that "special needs," administrative searches, and whatever other "categor[ies] of exceptions" exist occur infrequently. The first two were described as "limited exception[s]" to the baseline probable cause and warrant requirements of the Fourth Amendment. ${ }^{182}$ "Special needs" searches actually occur quite frequently as a corollary to the government's investigatory efforts. Scalia's opinion noted that roadblocks to discover intoxication are permitted by the government's interest in discovering drunken drivers. ${ }^{183}$ Other types of special needs are used far more commonly. Inventory searches, one of the many types of searches commonly permitted for a purpose other than criminal investigation, ${ }^{184}$ are permitted whenever a vehicle is impounded, to protect the seizing agency and storage facility from lawsuits for theft. ${ }^{185}$ Searches of inmates entering detention centers

180 al-Kidd, 131 S. Ct. at 2081.

I8I Justice Scalia, of course, generally prefers to uses formalistic rather than functionalistic reasoning. See Daniel Farber, The Ages of American Formalism, 90 Nw. U. L. Rev. 89, 9I ( 1995 ) (describing Scalia as "the leading judicial formalist of our day").

182 al-Kidd, 13 I S. Ct. at 2080.

183 Id. at 2081.

I84 See Scott E. Sundby, "Everyman" 's Fourth Amendment: Privacy or Mutual Trust Between Government and Citizen?, 94 CoLuM. L. REv. I751, 1752 ( I 994) ("Article after article documents ... how [the Court] has riddled the Warrant Clause with exceptions.").

I85 See Dimino, supra note 178 , at 1493 . 
are permitted to ensure the safety of the facility. ${ }^{186}$ Passengers may be ordered out of automobiles stopped for minor traffic offenses to ensure the safety of the officer. ${ }^{187}$

Why, then, is the government's interest in obtaining a witness's testimony at trial not a "special need"? Obviously, the testimony of witnesses is part of the prosecution process, but a witness's appearance is compelled without a demonstration of probable cause or judicial consideration in most cases. Lawyers issue subpoenas to witnesses whose testimony they find relevant. Certainly the ordinary process of securing a witness's appearance is not protected by a judicial determination of probable cause. Though a court has never so characterized the subpoena power, surely a "special need" explains why lawyers are permitted to determine when a witness's testimony is relevant and compel his presence. Material witness arrests are justified by the need to obtain the same goal the subpoena ordinarily achieves. By definition, such arrests are permitted only when use of the subpoena would be "impracticable." 188

Justice Scalia did not look to the goal of material witness arrests, which seemingly must be viewed as unrelated to the ordinary enforcement of criminal law, if subpoenas can continue to be issued without judicial supervision. Scalia looked at the process used to authorize material witness detentions to conclude that they did not fit within the "special needs" paradigm. ${ }^{189}$ As a "warrant issued by a neutral Magistrate Judge authorized al-Kidd's arrest" and "the warrant application ... gave individualized reasons to believe that he was a material witness and that he would soon disappear," Justice Scalia therefore concluded the arrest fit within the larger paradigm of cases, exemplified by Whren $v$. United States, for which government actors' subjective motives were irrelevant. ${ }^{190}$ "The existence of a judicial warrant based on individualized suspicion takes this case outside the domain of not only our special-needs and administrative-search cases, . but of Edmond as well." 191

As al-Kidd argued, however, Whren found only that an official's subjective motives are irrelevant where there is "probable cause to believe that a violation of law has occurred." ${ }^{192}$ The basis for al-Kidd's arrest was not related to any criminal wrongdoing on his part. His case did not fit into the Whren paradigm. Justice Scalia essentially relied on a principle of basic logic to negate this argument. Whren stood for the proposition that if a seizure is based on probable cause, then the officer's motives are

186 Illinois v. Lafayette, 462 U.S. 640,646 ( 1983$)$.

187 Maryland v. Wilson, 519 U.S. 408, 410 (1997).

I88 18 U.S.C. § 3144 (2006).

I89 Ashcroft v. al-Kidd, I3I S. Ct. 2074, 2082 (2011).

190 Id.

191 Id.

I92 Id. (quoting Whren v. United States, 517 U.S. 806, 8 I I (1996)). 
irrelevant. ${ }^{193}$ The inverse of this proposition is not necessarily true as a matter of pure logic. ${ }^{194}$ "[T]o say that ulterior motives do not invalidate a search that is legitimate because of probable cause to believe a crime has occurred is not to say that it does invalidate all searches that are legitimate for other reasons." 195 In typical Scalia fashion, he then added a gratuitous insult: "Only an undiscerning reader ... would think otherwise." 196

Of course the fact that Whren's holding does not logically require the conclusion al-Kidd sought does not mean that its reasoning does not help define the circumstances when a government actor's motivations are relevant. Certainly the true value of the inverse of the quotation from Whren is unknown as a matter of logic. ${ }^{197}$ Whren's observation that officers' motivation were not relevant where probable cause of wrongdoing exists does raise the possibility, if not the presumption, however, that an officer's motivations are relevant when probable cause of wrongdoing does not exist.

However, Scalia concluded suspicion of wrongdoing was not required. Individualized consideration of the facts allegedly justifying al-Kidd's arrest made the government actor's motivations irrelevant. ${ }^{198}$ Justice Ginsberg's concurrence observed that "the word 'suspicion' ... ordinarily indicates that the person suspected has engaged in wrongdoing." ${ }^{199}$ Scalia responded:

No usage of the word [suspicion] is more common and idiomatic than a statement such as "I have suspicion he knows something about the crime," or even "I have a suspicion she is throwing me a surprise birthday party." The many cases cited by Justice GINSBERG, which use the neutral word "suspicion" in connection with wrongdoing, prove nothing except that searches and seizures for reasons other than suspected wrongdoing are rare. ${ }^{200}$

The cases are sufficiently rare that the Court had never, prior to al-Kidd, considered the issue presented in this case. New law had to be carved to account for this situation despite Scalia's protests that this issue was clearly dictated by existing precedent.

193 See Craig M. Glantz, "Could" This Be the End of the Fourth Amendment Protections for Motorists?, 87 J. Crim. L. \& Criminology 864, 864 (1997).

194 See Karl J. Smith, Introduction to Symbolic Logic 36-37 (2d ed. I991).

195 al-Kidd, 13 I S. Ct. at 2082.

I96 Id. at 2082 (citation omitted) (internal quotation marks omitted).

I97 See Smith, supra note 194:

198 Justice Ginsberg contested Justice Scalia's conclusion that the government's evidence that al-Kidd had information, even if the evidence was compelling, amounted to individual suspicion as that term had been understood prior to the al-Kidd case. al-Kidd, I3 I S: Ct. at 2088 n.2 (Ginsberg, J., concurring).

199 Id. at 2088 n.3 (Ginsberg, J., concurring).

200 Id. at $2088 \mathrm{n} .2$ (Ginsberg, J., concurring) (citation omitted). 
The government had argued that if the motives for the detention were relevant, then witnesses suspected of nothing but possessing information could be held more readily than al-Qaeda members with information. ${ }^{201}$ The government, along with its arguments that the result in this case was dictated by precedent, had offered a practical consideration for resolving the case, but practical considerations were no part of the opinion. Justice Scalia's approach took care of this concern and had the effect of constricting the category of special needs searches, but did not offer an explanation for his new approach to the special needs category.

Having found the possible investigatory motives of a government actor seeking a material witness warrant constitutionally irrelevant, Justice Scalia spent little time concluding that John Ashcroft was not on notice that the Fourth Amendment precluded witness detentions for an investigative purpose. It is not clear why he needed to address this issue at all given that he first held that there was no Fourth Amendment violation. If there was no Fourth Amendment violation, there is no way Ashcroft could have been on notice of such a violation. ${ }^{202}$

The facts of the case, however, prevented these from being the last words of the case. Three members of the Court, Ginsberg, Breyer and Sotomayor, did not join the majority's conclusion that the pretextual use of material witness detentions did not violate the Fourth Amendment as each regarded resolution of this issue to be unnecessary to resolve the case. ${ }^{203}$ Justices Ginsberg observed the "serious questions, unaddressed by the Court, concerning the legality of the Government's use of the Material Witness Statute in this case." 204 Justice Ginsberg was particularly concerned about the affidavit the government filed in support of the arrest warrant, the government's omission of its disinterest in using his testimony at trial, and the "harsh custodial conditions to which al-Kidd was subjected," which she aptly described as "brutal." ${ }^{205}$ She also recognized that there was a threshold question about the factual basis supporting even the initial decision to arrest al-Kidd.

201 Brief of Petitioner at 39, Ashcroft v. al-Kidd, I3 I S. Ct. 2074 (2011) (No. 10-98), 2010 WL 5087872 ("[T]he fear of personal liability may dissuade prosecutors from obtaining such a warrant when they harbor any suspicion that the subject might be involved in criminal wrongdoing but do not yet have probable cause to bring criminal charges.").

202 See Pearson v. Callahan, 555 U.S. 223, 227 (2009) (overruling Saucier v. Katz, 533 U.S. 194 (200I), which previously required courts to decide whether a constitutional right had been violated before addressing whether the right was clearly established); Karen M. Blum, Section 1983 Litigation: Post-Pearson and Post-Iqbal, 26 Touro L. Rev. 433, 436-38 (2010).

203 See al-Kidd, 13 I S. Ct. at 2087 (Ginsberg, J., concurring); id. at 2089 (Sotomayor, J., concurring).

204 Id. at 2089 (Ginsberg, J., concurring) (citation omitted) (internal quotation marks omitted).

205 Id. 
Judicial officers asked to issue material witness warrants must determine whether the affidavit supporting the application shows that "the testimony of a person is material in a criminal proceeding" and that "it may become impracticable to secure the presence of the person by subpoena." 18 U.S.C. $\$ 3144$. Even if these conditions are met, issuance of the warrant is discretionary. Ibid. ("judicial officer may order the arrest of the person" (emphasis added)). Al-Kidd's experience illustrates the importance of vigilant exercise of this checking role by the judicial officer to whom the warrant application is presented.

The affidavit used to secure al-Kidd's detention was spare; it did not state with particularity the information alKidd purportedly possessed, nor did it specify how al-Kidd's knowledge would be material to Sami Omar al-Hussayen's prosecution. As to impracticability, the affidavit contained only this unelaborated statement: "It is believed that if Al-Kidd travels to Saudi Arabia, the United States Government will be unable to secure his presence at trial via subpoena." App. 64. Had the Magistrate Judge insisted on more concrete showings of materiality and impracticability, al-Kidd might have been spared the entire ordeal. ${ }^{206}$

While Justice Ginsberg raised a concern about the application of the materiality requirement of the Material Witness Statute, Justice Kennedy raised a brief, but poignant, question about the application of the impracticability requirement:

\begin{abstract}
Under the statute, a Magistrate Judge may issue a warrant to arrest someone as a material witness upon a showing by affidavit that "the testimony of a person is material in a criminal proceeding" and "that it may become impracticable to secure the presence of the person by subpoena." 18 U.S.C. $\$ 3144$. The scope of the statute's lawful authorization is uncertain. For example, a law-abiding citizen might observe a crime during the days or weeks before a scheduled flight abroad. It is unclear whether those facts alone might allow police to obtain a material witness warrant on the ground that it "may become impracticable" to secure the person's presence by subpoena. Ibid. The question becomes more difficult if one further assumes the traveler would be willing to testify if asked; and more difficult still if one supposes that authorities delay obtaining or executing the warrant until the traveler has arrived at the airport. These possibilities resemble the facts in this case. ${ }^{207}$
\end{abstract}

Justice Sotomayor's concurrence succinctly stated a sentiment that pervaded both Justice Kennedy and Justice Ginsberg's opinion: "[N] othing in the majority's opinion today should be read as placing this Court's imprimatur on the actions taken by the Government against al-Kidd." ${ }^{208}$

Interestingly, the Justice Department did not specifically seek review of the Ninth Circuit's conclusion that John Ashcroft's policies were

206 Id. at 2088 n.2.

207 Id. at 2085-86 (Kennedy, J., concurring).

208 Id. at 2090 (Sotomayor, J., concurring). 
sufficiently connected to the decision to seek an invalid material witness warrant to permit liability under Iqbal. Review was sought only of the Ninth Circuit's conclusion that "the Fourth Amendment prohibits an officer from executing a valid material witness warrant with the subjective intent of conducting further investigation or preventively detaining the subject." 209 Depending on what happens on remand, the former attorney general may still be liable for inadequately supervising material witness arrests to ensure that they are not sought when there is no basis for detention under the Material Witness Statute.

\section{Concerns That Were Not Before the Court}

It would have been illogical to permit the detention of a witness suspected of no wrongdoing, while forbidding the detention of one who possesses helpful information and is also suspected of wrongdoing. The reality, though, that the Material Witness Statute can be used as a method of investigating the witness's criminal act raises a set of concerns that need to be addressed by courts and legislatures. The abuses al-Kidd, and others like him, suffered should never again be tolerated.

Prosecutors and police can be largely trusted to self-regulate the treatment of a detained witness if these persons truly are merely persons whose testimony will be useful to the government. ${ }^{210}$ The government would have plenty of incentive to ensure at least decent treatment for those it wishes to use as witness and would be reluctant to detain those whose assistance alone was sought. ${ }^{211}$ The government would want these witnesses to testify to the best of their ability and forcible detention and poor conditions of confinement would surely undermine that goal. ${ }^{212}$ The witness-suspect can rely on no similar hope of self-restraint, as the plight of al-Kidd himself vividly demonstrates.

209 Petition for Writ of Certiorari, Ashcroft v. al-Kidd, 131 S. Ct. 2074 (201 1 ) (No. 10-98), 2010 WL 2830439 at *I.

210 In a case involving a cooperating witness suspected of criminal wrongdoing, the government's favorable treatment will often involve promises of leniency in punishment. See George C. Harris, Testimony for Sale: The Law and Ethics of Snitches and Experts, 28 PEPP. L. Rev. I, I 8 (2000) ("[I]t is well-established that prosecutors in federal criminal cases can offer lenient treatment and cash rewards to accomplices, informers, or other cooperating witnesses who testify for the government. The trend in modern federal case law is to accept even overtly contingent agreements for testimony." (footnotes omitted)).

21I See Ann C. Rowland, Effective Use of Informants and Accomplice Witnesses, 50 S.C. L. Rev. 679,679 (1999) ("Rarely are informants public-spirited citizens who volunteer solely because they have information that might be useful. Informants usually receive some compensation or benefit for their information in the form of a reward, regular monetary payments, reimbursement for expenses, or other benefit.").

212 See Daniel C. Richman, Cooperating Clients, 56 OHı ST. L.J. 69, Iо (1995) (observing that government will often reserve the terms of a plea deal to ensure that the defendant testifies to the best of his ability). 
The efforts to use the detentions to obtain evidence against the witness-suspect, though they raise thorny issues, can and likely will be resolved by courts. Limits on the government's ability to use the Material Witness Statute to preventively detain the witness-suspect, however, can only realistically be addressed by Congress.

The Material Witness Statute offers prosecutors a potential means of bypassing protections available to suspects in ordinary criminal investigations. Courts are, however, in a good position to evaluate the legitimacy of using these detentions to obtain evidence against suspects. Courts must necessarily pass on the admissibility of evidence in criminal cases, providing ample opportunity for the development of common law rules.

The use that courts may make of evidence obtained against witnesses will nevertheless present difficult questions. Consider the two most regulated aspects of police investigation - the seizure of physical evidence and extraction of statements from persons in custody.

It is not entirely clear whether physical evidence obtained incident to a material witness arrest may be used against the witness, regardless of the motivation for the arrest. ${ }^{213}$ Evidence obtained incident to material witness's arrest can be viewed either as the product of an ordinary arrest, in which case the only limitation would be the location of the evidence obtained. The government's interest in protecting officer safety and preventing suspects from destroying evidence in his possession justifies the search incident to arrest. ${ }^{214}$ If material witness arrests are treated like ordinary arrests, anything within the witness's grabbing area at the time of his arrest could be admitted against him in any criminal proceeding. ${ }^{215}$

Alternatively, these arrests could be viewed like the impoundment of an automobile. ${ }^{216}$ While a material witness is certainly an animate human being who may pose risks to the officer; like other arrestees, he is unlike an ordinary arrestee in that the government has not.shown that there is an evidentiary basis for believing him guilty of a crime. ${ }^{217}$ There is thus

213 One court has ruled that the fruits of a pretextual material witness arrest are inadmissible. State v. Hand, 242 A.2d 888, 897 (Sup. Cr. 1968).

214 See Thomas K. Clancy, The Framers' Intent: John Adams, His Era, and the Fourth Amendment, 86 IND. L.J. 979, 986 (201 I) (describing historical pedigree of search-incidentto-arrest doctrine).

215 The grabbing area doctrine has lately gone through a number of transformations when the person arrested was driving an automobile. See Arizona v. Gant, 556 U.S. 332 (2009). For competing views on the effect of Gant, compare Barbara E. Armacost, Arizona v. Gant: Does It Matter?, 2009 Sup. CT. Rev. 275 (2009) with Christopher D. Totten, Arizona v. Gant and Its Aftermath: A Doctrinal "Correction" Without the Anticipated "Gains", 46 CriM. L. Bull. 6 (2010). 2 I6 See Florida v. Wells, 495 U.S. I, 4 ( I 990); Colorado v. Bertine, 479 U.S. 367, 372 (1987); South Dakota v. Opperman, 428 U.S. 364, 375-76 (1976).

217 Terry $v$. Ohio is another example of the potential of a defendant's danger being insufficient for a government intrusion. A pat-down is justified if the officer has reasonable suspicion 
no legal basis for suspecting that he will have evidence to destroy. Under current law, this would not itself raise a question about the government's right to take the same precautions it takes when detaining others. ${ }^{218}$ The same fear of pretext that animates an inventory search of an impounded car, however, animates the search-incident-to-arrest of a material witness. ${ }^{219}$ The arrest could well be an effort to conduct a search unsupported by any legal foundation and, while problematic in itself, could dramatically increase the use of witness detentions.

The logical extension of Justice Scalia's majority opinion in al-Kidd would suggest that material witness arrests are no different than ordinary arrests as each are supported by individualized suspicion, a characterization challenged by three concurring justices. ${ }^{220}$ Viewing material witness arrests as functionally identical to ordinary arrests, however, would confer on prosecutors and police the power to draw inferences about group criminality that the Supreme Court has long rejected. Consider the facts of Ybarra $v$. Illinois. ${ }^{221}$ Police officers had probable cause to believe that the bartender of the Aurora Tap Room was selling heroin and obtained a warrant to search the bar and the bartender. ${ }^{222}$ In executing the warrant, officers also patted down patrons of the bar discovering heroin in a cigarette pack on Ventura

that the suspect is armed and dangerous and has committed, or is about to commit, a crime. Suspicion of danger alone is insufficient for a pat-down. See Terry v. Ohio, 392 U.S. 1, 26-27 ( 1968 ); see also Arizona v. Johnson, 555 U.S. 323,326 (2009) (noting the two separate requirements, suspicion of wrongdoing and reason to believe the suspect is armed and dangerous, to permit pat-down).

218 To the contrary, however, the Court has held that once an arrest is legitimate, the government's interest in officer safety permits a search incident to arrest, even if there is almost no reason to think the arrestee will possess evidence of a crime. See United States v. Robinson, 414 U.S. 218,235 (1973).

219 No doubt the difficulty of administrability is a big part of the Supreme Court's reluctance to include a concern about pretext in its criminal procedure cases. Technically, inventory searches of impounded automobiles are forbidden if the search is motivated by the officer's interest in searching for evidence. If conducted for a reason other than protecting the impounding authority from civil suits for theft or damage, such searches are forbidden by the Fourth Amendment. See supra notes $183-84$ and accompanying text. Demonstrating that the search was conducted for the illegitimate basis of searches for evidence is, as a practical matter, nearly impossible. The Supreme Court has held that the search is legitimate if consistent with the plan developed to search all such impounded cars. Lower courts have held that such plans need not be written. In one particularly noteworthy case, the Sixth Circuit held that the inspection of a vehicle's engine block was consistent with a non-pretextual inventory search. Inventory searches must.merely be consistent with a policy, which is not required to be written. Chad Carr, To Impound or Not to Impound: Why Courts Need to Define Legitimate Impoundment Purposes to Restore Fourth Amendment Privacy Rights to Motorists, 33 Hamline L. Rev. 95, I I2-I3 (2010).

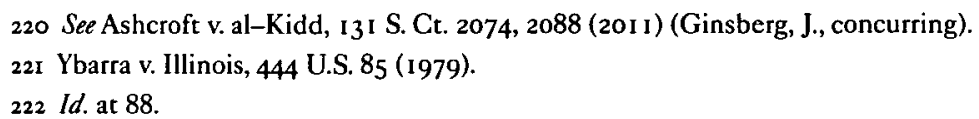


Ybarra. ${ }^{223}$ If pretext is irrelevant in how we view evidence obtained in a material witness arrest, imagine the slightly different application that would have been presented to the magistrate in the Ybarra case. Officers would have sought warrants to arrest the patrons to the bar as material witnesses to the drug dealing inside. ${ }^{224}$ The fear of this sort of creative use of material witness detentions is particularly acute if warrants are not constitutionally required for material witness arrests, another issue yet to be resolved. ${ }^{225}$

Once arrested, is the material witness in custody for the purpose of Miranda v. Arizona? The answer initially appears to be an unequivocal "yes" as the detainee is most emphatically in custody. If the suspect is arrested on suspicion of a robbery, he may not be questioned about an unrelated murder unless he waives his Miranda rights to silence and presence of counsel at questioning. ${ }^{226} \mathrm{He}$ can waive his rights when he thinks he is just being investigated for the robbery and that waiver is valid even if the subject matter changes to a different, and even substantially more serious, crime, but there must be a waiver. ${ }^{227}$ Likewise it might seem readily obvious that the interrogation of an arrested material witness may not be admitted unless the detainee waives his Miranda rights. Law enforcement officers who arrest the witness on one basis seemingly would not be permitted to question him about other matters without a Miranda waiver at some point.

The answer is not, however, that easily resolved. If the police question a person serving a prison sentence, or judicially committed to a mental hospital, Miranda warnings are not required so long as officers impose no additional constraints on freedom. ${ }^{228}$ Courts may well conclude that if officers are detaining the witness for a purpose other than prosecuting him, his confinement, like that of the state prisoner or mental health patient, is not for the purpose of criminal investigation, making the Miranda warnings

223 Id. at 89.

224 Loose interpretations of materiality and impracticability could make this concern less than far-fetched. Limits on materiality could also prevent this sort of problem. See discussion at infra note 226-31 and accompanying text.

225 Certainly the federal Material Witness Statute and the Material Witness Statutes in most states provide for a warrant for a material witness arrest. They do not, however, provide that material witness arrests require a warrant. Even if they did expressly limit material witness arrests to those authorized by warrant, these statutes would be largely irrelevant if a court were to conclude that warrants were not constitutionally required to arrest material witnesses. See Virginia v. Moore, 553 U.S. I64, 177-78 (2008) (holding that the Fourth Amendment does not forbid an arrest for even petty offenses, and officers' violations of state statutes requiring citations in lieu of arrests would not require evidence obtained incident to arrest to be excluded).

226 See Adam J. Hegler, Is the Temple Collapsing?: Montejo v. Louisiana and the Extent of the Right to Counsel in Criminal Proceedings, 6I S.C. L. REv. 867, 873-74 (2010).

227 Id.

228 See Kit Kinports, The Supreme Court's Love-Hate Relationship ewith Miranda, I 1 I. CRIm. L. \& Criminology 375, 382-89 (201 I); Laurie Magid, Questioning the Question-Proof Inmate: Defining Miranda Custody for Incarcerated Suspects, 58 OHIO ST. L.J. 883, 94 I-43 (I 997 ). 
unnecessary. ${ }^{229}$ The Justice Department apparently concluded that this was the likely approach courts would take as they did not give al-Kidd his Miranda warnings before questioning him after his arrest. ${ }^{230}$ Obviously, if this is a valid interpretation of the Miranda protections, or lack thereof, for material witness detainees, prosecutors and police have a real incentive to rely heavily on their power to detain material witnesses. Such detentions would provide a bypass to the current scheme of regulating interrogations. ${ }^{231}$

As problematic as these concerns are, they are well within the ability of courts to address. Courts, in fact, must address these issues whenever the prosecution attempts to use evidence obtained from a material witness arrest to convict the witness himself. Once the witness becomes a defendant, he will be represented by counsel who will challenge the legality of the government source of all the evidence it is using against him. ${ }^{232}$ If the government or states start to use material witness detentions

229 One could look to the Miranda rights of a pretrial detainee as a basis for resolving this issue. Once a magistrate has decided that a criminal defendant must be held pending trial to ensure his presence and the safety of the community, the considerations justifying his detention are not formally about the investigation of a crime. The basis of pretrial detention is identical to the basis for a material witness arrest and detention. The Sixth Amendment precludes the prosecution from questioning the defendant about crime for which he is detained. While the amendment is offense-specific, the defendant is a represented party once he is committed to jail pending trial, thus forbidding the government from communicating with him under most rules of ethics. Rarely, then, has there been an occasion for a prosecutor to attempt to question a suspect being held pending trial about an unrelated matter without implicating other rules of criminal procedure.

230 First Amended Complaint and Demand for Jury Trial, supra note 14, at *29-30.

23I The protections provided by Miranda have been substantially weakened in the recent terms of the United States Supreme Court. See Barry Friedman, The Wages of Stealth Overruling (With Particular Attention to Miranda v. Arizona), 99 GEo. L.J. I, I6-25 (20 I0). The Court has not, however, said that police departments can decide that they will interrogate without using the warnings and still admit the confessions. This view of the protections afforded detained material witnesses in interrogations would provide the police just that power. A material witness warrant could come to be the preferred warrant if the rules of interrogation are more favorable to the police.

232 There is, in fact, an almost knee-jerk response defense lawyers have to seek to exclude evidence that could in any way harm their clients' cases. One by-product of the legal academy's case law approach to learning has been to make defense lawyers very.good at looking at police reports to determine whether there is a basis to challenge the admissibility of incriminating evidence. Cf. William J. Stuntz, The Virtues and Vices of the Exclusionary Rule, 20 Harv. J.L. \& Pub. Pol'y 443, 453 (I997) (observing that over-worked public defenders will frequently allocate resources toward excluding illegally obtained evidence). Lawyers are much better at excluding than discovering evidence. The academy has done a poor job teaching lawyers how to investigate. Prosecutors, of course, rely on the professional investigators, the police. Defense lawyers often do not have the luxury of having an investigator as part of a defense team. Two pieces of evidence reveal the inadequacy of legal training to equip lawyers to deal with this important aspect of their jobs. Five instances of wrongful conviction were discovered on Illinois' death row by Northwestern graduate students, but not students in the law school. Journalism students, who are trained to find facts, discovered these egregious errors. See Brian Rosenthal, In Focus: Investigative Journalism Students Used Questionably 
as a means of collecting physical evidence or extracting confessions, courts will be presented with the legitimacy of these methods. Courts will also have an interest in ensuring that the protections they have fashioned not be obliterated by a prosecution theory - a little too clever by seven-eighths - that a search of a person, or a custodial interrogation, is exempt because the target is called a "witness."

Courts are in a poor position, by contrast, to develop protections against the non-investigatory aspects of material witness detentions, regardless of whether the witness is suspected of wrongdoing and detained preventively or genuinely held to guarantee his testimony. What is a sufficient factual basis for detaining a witness? What constitutes sufficient evidence that a subpoena will not practically secure the witness' appearance? How long may witnesses be detained? Is a witness entitled to a hearing before he is arrested? What are the terms of confinement for witnesses? For a variety of reasons, these questions are not easily answered by courts.

The materiality and impracticábility requirements of the Material Witness Statute are too vague to provide notice about who may be detained. It is not clear how essential a witness's testimony must be for it to meet the materiality standard in the statute. Typically, claims that statutes are void for vagueness are made about provisions of the criminal code. ${ }^{233}$ Vague statutes raise concerns about an individual's ability to know what the statute proscribes. ${ }^{234}$ Without adequate clarity, it is impossible to avoid committing proscribed conduct. Material witness detentions obviously do not depend on a witness's wrongdoing. There is nothing inherently wrong about possessing information material to a prosecution. It is not clear that citizens would know how to avoid knowing information helpful to a criminal prosecution and, even they could, it is even less clear that society would be better if they did so. ${ }^{235}$

Ethical Reporting Tactics, Sources Say, DaILY Nw., May 4, 201 I, http://www.dailynorthwestern. com/campus/in-focus-investigative-journalism-students-used-questionably-ethical-reporting-tactics-sources-say-1.255886 I\#.TrcHgXPgAqk. Secondly, the number of death sentences in this country has been dramatically dropping because the defense of capital cases has come to involve telling the defendant's own human story, rather than attempting to somehow minimize the crime he committed. This innovation was not developed by lawyers but by mitigation specialists, generally trained in social work. See Jeffrey Toobin, The Mitigator, New YORKER, May 9, 201 I , http://www.newyorker.com/reporting/20 I I/05/09/1 10509fa_fact_toobin. Lawyers are not particularly good at a number of things their jobs require, but they are very good at discovering how the exclusionary rule can be used to their client's advantage, thus assisting courts in placing limits on government investigations.

233 See, e.g., Eric J. Miller, The Warren Court's Regulatory Revolution in Criminal Procedure, 43 Conn. L. Rev. I, 73 (2010) (observing that "[i]n a variety of civil rights cases, the Court has developed the doctrines of void-for-vagueness and overbreadth to place limitations on substantive criminal law statutes.").

234 See Kim Forde-Mazrui, Ruling Out the Rule of Law, 60 VAND. L. Rev. 1497, I510-I I (2007) (describing constitutional prohibition on vague criminal laws).

235 The fear of being detained as a material witness led many to deny knowledge of 
The impracticability of the subpoena requirement also suffers from lack of clarity. What actions sufficiently demonstrate that it would be "impracticable to secure the presence of the person by subpoena"? ${ }^{236}$ Is international travel sufficient? Does the witness have to manifest his refusal to assist the government? What is sufficient evidence of such a refusal? The statute provides no indication to witnesses about the steps they must take, or not take, to demonstrate they will comply with a subpoena.

The other concern typically raised with vague criminal statutes is arbitrary enforcement. ${ }^{237}$ With the Supreme Court's decision in al-Kidd, arbitrary enforcement becomes a very real concern. The requirements of materiality and impracticability should prevent prosecutors from having unchecked power to order the arrest - and seek the detention - of any persons they choose. But with little guidance on how to decide cases, judicial considerations of applications for material witness warrants could therefore easily turn on the extent to which the government describes a basis to fear the witness, rather than reasons he will be unavailable to provide valuable testimony.

Just how important must the witness's testimony be to the government's case to permit an arrest? The statute certainly does not require that the testimony be offered at trial. The prosecutor's contemplation that the testimony would be useful to a grand jury's investigation would appear to be facially sufficient.

Materiality has been defined in other contexts, but none sufficiently analogous to material witness detentions to define the limits on these arrests. ${ }^{238}$ To issue a subpoena in another state, a party to litigation must demonstrate that the witness's testimony would be material. ${ }^{239}$ In this context, some courts have refused to issue subpoenas if the requested testimony is not adequately described in the request, ${ }^{240}$ is speculative, ${ }^{241}$

events surrounding crimes in late nineteenth century New York. This concern was so pressing that the New York Police Department asked the legislature to abolish the power to detain witnesses to alleviate the public's concern. See Oliver, supra note 82, at 776 .

236 I 8 U.S.C. $\$ 3144$ (2006).

237 See Oliver, supra note 82, at 776.

238 See Wendy Gerwick Couture, White Collar Crime's Gray Area: The Anomaly of Criminalising Conduct Not Civilly Actionable, 72 ALB. L. Rev. I, 28-29 (2009) (observing low standard of materiality in wire and mail fraud statutes); Bennett L. Gershman, The "Perjury Trap", I 29 U. PA. L. REv. 624, 688 ( I 98I) ("In view of the attenuated concepts of materiality that have been articulated in the context of the various federal and state perjury statutes, this requirement is of little practical value." (footnote omitted)); Ellen S. Podgor, Making 'Materiality' an Element of Obstruction of Justice, The Champion, Sept:-Oct. 2005, at 26.

239 See Unif. Act to Secure the Attendance of Witnesses from Without a State in Criminal Proceedings $\$ 3$ (1936).

240 See Commonwealth v. Beneficial Fin. Co., 275 N.E.2d 33, 100 (Mass. 1971); People v. McCartney, 345 N.E.2d 326, 329 (N.Y. 1976); Weaver v. State, 657 S.W.2d 148, 150-5 I (Tex. Crim. App. 1983).

24I See Commonwealth v. Smith, 561 N.E.2d 520, 524-25 (Mass. App. Ct. 1990); Bell v. 
or is even duplicative of other testimony. ${ }^{242}$ The Utah Supreme Court even held that the materiality requirement for an out-of-state subpoena was satisfied only if there was a plausible showing that there was a reasonable probability that the testimony would affect the outcome of a trial. ${ }^{243}$ These limits on materiality in the issuance of interstate subpoenas for witnesses do not even presently apply to the government's efforts to arrest a witness. Seemingly, these limitations should apply to the government's efforts to make an arrest under the Material Witness Statutes.

Materiality is also defined in perjury and fraud statutes. ${ }^{244}$ Borrowing from cases interpreting the term in this context raises a similar set of problems. A broad view of materiality in these contexts encourages truthtelling. A broad reading of materiality in the context of material witness detentions opens wide the scope of persons whom the government may arrest for possessing information.

With few material witness arrests, and almost no practical opportunity for appellate review of the circumstances leading to the arrests, magistrate judges have only the limited guidance interpreting materiality that comes from these other statutes. The facts in the al-Kidd case reveal how little guidance courts are given. A federal magistrate judge found the government had sufficiently demonstrated that materiality had been satisfied, even though Justice Breyer in the oral argument strongly suggested it had not been and Justice Ginsberg concluded that it had not been in her opinion. ${ }^{245}$ The limited number of opportunities for courts to develop criteria construing materiality in this context leaves Congress in a better position to flesh out the meaning of this vague term.

Similar issues are raised by the criteria requiring the government to show "it may become impracticable to secure the presence of the person." 246 In his opinion, Justice Kennedy raised a concern about the very broad basis the statute gives the government to arrest a witness. Kennedy queried whether a planned trip out of town was sufficient to justify an arrest, especially if the witness agreed to appear when required by subpoena. ${ }^{247}$ Predictions

State, 885 P.2d 1311 (Nev. 1994).

242 See State v. Smith, 753 P.2d I 174, I 179 (Ariz. Ct. App. 1987); People v. McKinney, 157 Cal. Rptr. 41 4, 43 I (Cal. Ct. App. 1979); People v. Burt, 658 N.E.2d 375, 387 (Ill. 1995); State v. Chapman, 655 P.2d I I 19, I 123 (Ủtah 1982).

243 State v. Shreuder, 712 P.2d 264, 274-75 (Utah 1985).

244 See, e.g., Gershman, supra note 238 , at 688-90 (describing materiality as a common requirement of perjury statutes); James B. Helmer, Jr. \& Julie Webster Popham, Materiality and the False Claims Act, 71 U. Cin. L. Rev. 839, 840-4I (2003); Stefan J. Padfield, Immaterial Lies: Condoning Deceit in the Name of Securities Regulation, 61 CASE W. RES. L. REv. 143, 150-52 (2010) (describing materiality in stock fraud context).

245 See Transcript of Oral Argument, Ashcroft v. al-Kidd, I 3 I S. Ct. 2074 (201 I) (No. I098), 20 I I WL 7 I 962 I at * 13-I4; al-Kidd, I3 I S. Ct. at 2088 (Ginsberg, J., concurring).

24618 U.S.C. $\$ 3144$ (2006) (emphasis added).

247 al-Kidd, I3 I S. Ct. at 2085-86 (Kennedy, J., concurring). 
of future conduct are inherently unreliable. ${ }^{248}$ Seizures or detentions of persons have, in other contexts, been permitted only on predictions of future dangerousness. ${ }^{249}$ The Material Witness Statute involves a prediction that a witness will not comply with a subpoena.

One solution to Fourth Amendment concerns about an arrest based on future unavailability is to provide the witness a hearing before he is arrested, which would give him an opportunity to demonstrate that he will appear before he is arrested. Some states have developed such a rule by legislative act, or judicial interpretation of constitutional limits on seizures. ${ }^{250}$ With such a limitation, material witness warrants essentially become super-subpoenas, issued for the witness's appearance in advance of trial to provide the court an opportunity to assess what restraints are necessary. If the witness fails to appear for this hearing, the court obviously has the power to order his arrest for contempt. As the federal statute reads, there is no requirement that the government show that the witness would not comply with a requirement that he appear at such a hearing, or that too much risk would be involved in waiting to see if the witness failed to comply. Congress has demonstrated considerable competency in identifying criteria courts ought to consider in determining what conditions will ensure a defendant's (or indeed, a witness's) appearance at trial in the Bail Reform Act. Congress could and should identify the criteria that permit essentially an emergency detention before the witness has a chance to be heard on the conditions that will ensure his presence. As Justice Kennedy described, the impracticability requirement provides almost no guidance to judges hearing material witness detention hearings.

Statutory or constitutional terms that lack precision are not as problematic in other contexts. Frequently vague terms are clarified through judicial application. The imprecision of materiality and impracticability present concerns in this context that similarly imprecise terms would not present

248 See Adam Lamparello, Using Cognitive Neuroscience to Predict Future Dangerousness, 42 Colum. Hum. RTs. L. Rev. 48I, 488-89 (201 I) (recognizing difficulty of predicting future dangerousness but proposing ways in which neuroscience can aid in that assessment).

249 Pretrial detention, incarceration of sex offenders after they serve their sentences, death sentences in some jurisdictions, and involuntarily commitments can all be based on predictions of future dangerousness. See Elyce H. Zenoff, Controlling the Dangers of Dangerousness: The ABA Standards and Beyond, 53 GEO. WASH. L. Rev. 562, 562 n.2 (1985).

250 A number of states have such provisions. See PA. R. CRIM. P. 522 (2010). Other states are more ambiguous. Alabama and Tennessee each provide, for instance, that a magistrate may require a material witness, who has either refused to comply with a subpoena in the past, or will do so in the future, to secure his appearance with bond. ALA. CoDE $\$ 1$ 5-I I-I 2(a) (1995); Tenn. Code Ann. § 40-1 1-1 10 (2006). These statutes do not appear to be used often as each note that the magistrate may, in his discretion, require bond of married women and minors. Ala. Code § 15-I 1-I3 (1995); TenN. CoDe ANN. § 40-10-1 10. Alabama provides that the witness may be required to enter into a bond for \$IOO. ALA. CODE $\S$ I 5-I I-I2(a). If a witness is unlikely to appear, it seems doubtful that a secured or unsecured bond - or even cash bond of $\$$ Ioo will impose a condition sufficient to ensure compliance. 
in other contexts. The law certainly is comfortable with vague terms. Probable cause, for instance, is one of the best known of them. Officers, however, have a reasonable sense of what it means to have probable cause because courts are constantly interpreting this term. Criminal defendants who have been the subject of searches - and with our drug laws there are plenty of those - are highly incentivized to object to the legitimacy of searches. They are given lawyers who, at least in many drug cases, know that a successful suppression motion ends the prosecution's case. These defendants, who are provided the right to counsel through the appellate stage, are constantly forcing the creation of reported decisions fleshing out the contours of search and seizure law. There is no dearth of judicial gloss on the Framer's vague term "probable cause."

The rarity of material witness detentions raises an odd civil rights concern for those witnesses the government may consider detaining in the future. There cannot be an adequate body of law clarifying the vague materiality and impracticality terms in the Material Witness Statute. Not only are material witness arrests infrequently sought, appellate review of arrest and detention decisions are even rarer. ${ }^{251}$ The witness is provided counsel at the detention hearing, which provides an opportunity and incentive for the witness to argue that neither of the requirements for his arrest were met. If these requirements have not been demonstrated, then he should simply be released without any conditions. The Bail Reform Act, however, provides no right to counsel if he chooses to appeal restrictions placed on him at the hearing. ${ }^{252}$ Unlike a criminal defendant, who is appointed counsel for any matters arising during the course of his prosecution, a witness's brief representation ends with the detention hearing. A criminal defendant has a constitutional right to counsel on appeal. ${ }^{253}$ An arrested witness has no constitutional right to counsel on appeal or otherwise. ${ }^{254}$ Magistrate judges rarely have occasions to interpret materiality and impracticability in the context of material witness detentions; district and appellate judges almost never have such opportunities. Congress is thus not only in the best position to offer better definitions of these vague terms, in many ways, but it is also

251 The Iowa Supreme Court recently held, in an unusual appellate decision interpreting the limits of material witness detentions, that under Iowa's poorly drafted material witness statute, a witness may only be detained until an indictment is handed down, which permits the issuance of subpoenas. In re Marshall, 805 N.W.2d I45, I62 (Iowa 201 I).

252 See 18 U.S.C. \& 3142 (2006).

253 See Douglas v. California, 372 U.S. 353, 356-57 ( 1963 ) (holding that indigent defendants have a right to counsel on appeal); see also Draper v. Washington, 372 U.S. 487, 497-98 ( 1963 ) (holding that indigent defendants must be provided with free transcript).

254 Courts have yet to address this issue, but the trend in the United States Supreme Court would suggest that the Court is not receptive to such a claim. See Turner v. Rogers, I3 I S. Ct. 2507,2515-16 (2011) (holding that a defendant has no right to counsel where incarceration is possible in civil contempt proceeding). 
in the only position to tighten the criteria determining when an individual may be arrested on the basis that he possesses information.

Once a witness is then arrested, there are substantial issues regarding the terms of his confinement that are also poorly suited for judicial restriction. A large portion of al-Kidd's complaint related to the terms of his confinement prior to the detention hearing. ${ }^{255}$ Courts have shown little interest in defining the terms of confinement for a person in federal custody. A federal court, which certainly has access to criminal records and the very extensive reports prepared by Pre-Trial Services, may make only recommendations to the Federal Bureau of Prisons about the location or even level of confinement. ${ }^{256}$ Courts would seem to have a vested interest in ensuring that they have control over both the length and terms of sentences they render. While many federal judges criticized the highly restrictive quality of the Federal Sentencing Guidelines, and some even resigned over them, there has been no similar judicial outrage over the limited role federal judges have to decide how prisoners should be confined. ${ }^{257}$ Just as a pre-trial detainee may present unique security risks, the same could be true for a material witness. Congress, however, has demonstrated a unique ability in this area with the Bail Reform Act. ${ }^{258}$ Just as it described the conditions bearing on whether a pre-trial detainee should be admitted to bail, it should describe the terms of confinement appropriate for material witnesses. Presumably that would involve the most minimal degree of custody imaginable absent circumstances that would be identified.

Once a federal judge determines that a witness may be detained, a poor bit of legislative drafting has left uncertain exactly how he can obtain his freedom prior to the trial for which his testimony is needed. Under the statute, "[n]o material witness may be detained because of inability to comply with any condition of release if the testimony of such witness can adequately be secured by deposition." 259 How is the magistrate to decide whether a deposition is sufficient? In over half of the material witness detentions after September 11, federal judges refused requests to allow material witnesses to submit to depositions. ${ }^{260}$ Just as with the materiality requirement itself, there is no criteria for establishing the government's

255 See First Amended Complaint and Demand for Jury Trial, supra note 14, at *20-22.

256 Yana Dobkin, Cabining the Discretion of the Federal Bureau of Prisons and the Federal Courts: Interpretive Rules, Statutory Interpretation, and the Debate Over Community Confinement Centers, 9 I Cornell L. Rev. 17 I, 180-81 (2005).

${ }_{257}$ See Richard T. Boylan, Do the Sentencing Guidelines Influence the Retirement of Federal Judges?, 33 J. Legal Stud. 23 I, 243 (2004); Kate Stith \& Steve Y. Koh, The Politics of Sentencing Reform: The Legislative History of the Federal Sentencing Guidelines, 28 Wake Forest L. REv. 223, 244 (1993); Criticizing Sentencing Rules, U.S. Judge Resigns, N.Y. Times, Sept. 30, 1990, at A22. 258 See Robert S. Natalini, Comment, Preventive Detention and Presuming Dangerousness Under the Bail Reform Act of 1984 , 34 U. PA. L. Rev. 225, 225-26 (1985).

259 I 8 U.S.C. $\$ 3144$ (2006).

26o See Carlson, supra note 148 , at 966-7I. 
need for live as opposed to transcribed testimony, and the nature of these cases do not provide a ready mechanism for the development of common law on this issue.

How long may those witnesses detained after arrest, and denied an opportunity to be deposed and released, be held? Must they be released after an appearance before a grand jury? After their appearance at trial? May they be held for a re-trial or for a trial on other defendants in the same matter? Does an individual's liberty interest not, at some point, trump the government's interest in ensuring a conviction? Comparing the Courtcreated rules under the constitutional guarantee to a speedy trial with the Congressionally-created Speedy Trial Act demonstrates the superior institutional ability of Congress to address this concern. The Court's speedy trial jurisprudence is laden with vague factors that generally ensure a government victory. ${ }^{261}$ While the Speedy Trial Act is certainly not a loophole-free piece of legislation, clear timelines are identified that courts are generally reluctant to draw. ${ }^{262}$

For a number of reasons, Congress is in the best position to take up the very troubling issues raised by the $A l-$ Kidd case.

\section{CONCLUSION}

The al-Kidd decision is something of a tempest in a teapot. Despite the conflicting legal precedent that lent no easy doctrinal answer, the Court's holding was practically inescapable. It should not be easier to arrest a bystander than a suspected terrorist. The Court's holding, though, may be meaningless to the parties in this case. John Ashcroft's policy of aggressive detaining witness, even if legal, appears to be sufficient, under an unchallenged aspect of the Ninth Circuit's opinion, to have required him to ensure detentions were sought consistent with the statute.

The practical effect of the al-Kidd decision will hopefully be legislative reform. The broad and vague terms of the Material Witness Statute cannot wait for judicial restrictions. Witnesses lack the means or incentive to challenge their arrests or conditions of release. Combined with the small number of material witnesses detained each year, these facts ensure that courts are given few opportunities to restrict the government's power under this statute. Leaving the statute unaltered is unacceptable. These rare

26I See George C. Thomas III, When Constitutional Worlds Collide: Resurrecting the Framers' Bill of Rights and Criminal Procedure, I00 Мich. L. Rev. 145, 227-28 (2001) (describing the Speedy Trial Act as adding detail to the Supreme Court's vague standard). But see Greg Ostfeld, Speedy Justice and Timeless Delays: The Validity of Open-Ended "Ends of Justice" Continuances Under the Speedy Trial Act, 64 U. Chi. L. Rev. 1037 (1997) (observing that timetable provided in the Speedy Trial Act can be somewhat easily circumvented).

262 Justice Scalia's recent decision in Maryland v. Shatzer, 130 S. Ct. 1213,1223 (2010), allows police to re-request a Miranda waiver after a fourteen-day waiting period provides a rare contrast to the vague time limits the Supreme Court typically establishes. 
detentions will continue to occur, most often under the radar, governed only by the vague language of the Material Witness Statute. Our government cannot be permitted to treat another citizen as it did Abdullah al-Kidd. 